\title{
O JOVEM NESTOR COMO LEÏSTÉR (SAQUEADOR) NA ILÍADA E O TEMA DA RAZIA DE GADO EM HOMERO
}

\author{
Leonardo Medeiros Vieira* * Instituto de Letras \\ da Universidade \\ Federal da Bahia.
}

RESUMO: Por meio da análise do episódio de razia de gado (boèlasía) seguido por uma batalha campal, narrado por Nestor no décimo primeiro canto da Ilíada (v. 670-762), este artigo procura fornecer subsídios para a caracterização da boēlasía como um tema tradicional da épica homérica. Ao longo do texto, a consideração dos elementos recorrentes na estrutura e na dicção das passagens analisadas, aliada ao estudo da relação entre a razia de gado e outras atividades ou situações (tais como emboscadas e a representação do ataque de feras contra gado nos símiles), permite formular um desenho inicial das características e associações típicas desse tema em Homero.

PALAVRAS-CHAVE: razia de gado; Nestor; Homero; épica arcaica.

$$
\begin{array}{r}
\text { LE JEUNE NESTOR COMME LEISTER (PILLARD) } \\
\text { DANS L' ILIADE ET LE THÈME DE LA RAPINE } \\
\text { DE BÉTAIL CHEZ HOMÈRE }
\end{array}
$$

RÉSUMÉ: A travers une analyse de l'épisode de rapine de bétail (boèlasía) suivi d'une bataille rangée, raconté par Nestor dans l'onzième chant de l'Iliade (v. 670-672), cet article se propose de fournir des éléments pour la caractérisation de la boèlasía comme un thème traditionnel de l'épopée homérique. Tout au long du texte, la considération des éléments récurrents dans la structure et dans la diction des extraits analysés, liée à l'étude du rapport entre la rapine de bétail et d'autres activités ou situations (telles que les embuscades et la représentation de l'attaque des bêtes sauvages contre le bétail dans les comparaisons), nous permet de formuler un premier dessin des caractéristiques et des associations typiques de ce thème chez Homère.

MOTS-CLÉS: rapine de bétail; Nestor; Homère; épopée archaïque. 


\section{A tradicionalidade da razia de gado e a boélasía de Nestor}

Estrangeiros, quem sois? Donde navegais pelas vias úmidas?
Vagais com algum propósito ou a esmo,
como saqueadores (lë̈stêres) sobre o mar, que vagam
arriscando as suas vidas e trazendo o mal para homens de
outras terras?

$(\text { iii, } 71-4)^{1}$

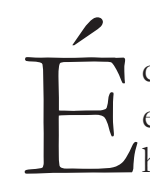

desse modo que o velho herói Nestor, após acolher os recém-chegados Telêmaco e Atena/Mentor com a refeição devida, indaga sobre a identidade de seus estimados hóspedes no princípio do terceiro canto da Odisseia. ${ }^{2}$ Desde Tucídides (Historiai, I, 5), o fato de este questionamento não ser encarado como ofensa pelos seus destinatários tem sido interpretado como uma evidência da naturalidade, da ubiquidade e da falta de estigma da prática da razia ou do saque (lëisteía), seja ele marítimo ou terrestre, na poesia homérica.

Tal constatação é reforçada por outras passagens do mesmo poema, tal como a fala subsequente do próprio Nestor que, em resposta a Telêmaco, refere-se aos sofrimentos que os aqueus padeceram, seja ao lutarem em torno de Troia, seja errando com as naus "em busca de butim" (katà lếida) por onde quer que Aquiles comandasse (iii, 105-6).

Outro passo da Odisseia fornece um importante testemunho acerca do caráter proveitoso da razia, que possibilitaria até uma certa ascensão social para aqueles que a priori

\footnotetext{
${ }^{1}$ Ao longo do texto, a referência aos poemas homéricos (sempre citados de acordo com as edições de Helmut van Thiel) será feita sem chamada, apenas por meio da indicação do livro em algarismos romanos maiúsculos para a Ilíada e minúsculos para a Odisseia. Todas as traduções dos textos antigos e de seus comentadores são minhas. Este trabalho é parte da minha pesquisa de doutoramento junto ao Programa de Pós-graduação em Letras Clássicas da FFLCH-USP, sob a orientação do Prof. Dr. Christian Werner.

${ }^{2}$ Esse mesmo bloco formular também ocorre em ix, 252-5 (Polifemo questiona Odisseu e seus companheiros) e no Hino homérico a Apolo, 453-6 (Apolo questiona os marinheiros cretenses). Além dessas três instâncias, o termo lëistér também ocorre em mais cinco passagens do corpus conservado da épica arcaica: em xv, 427 e xvi, 426 (aplicado a saqueadores táfios); em xvii, 425 (aplicado aos companheiros de razia do Odisseu/mendigo); no Hino homérico a Deméter, 125 (aplicado aos fictícios raptores de Deméter, disfarçada de anciã); no extenso Hino bomérico a Hermes, 14 (aplicado ao pequeno deus ladrão); e no segundo Hino homérico a Dioniso (aplicado a saqueadores tirsênios). Dentre as ocorrências apontadas, apenas aquela do Hino homérico a Hermes não está associada à atividade marítima. Uma vez que esse termo - cognato do substantivo lềis ('butim, saque'), do verbo lếsdomai ('levar como butim, saquear') e do adjetivo lëistós ('saqueável') - é usado (na língua grega dos períodos clássico, helenístico e imperial) tanto para agressores que atacam partindo do mar, como para aqueles que atuam apenas em terra, optei aqui por traduzi-lo por 'saqueadores' e não pelo costumeiro 'piratas', preservando a ambiguidade característica do termo. Acerca dessas questões e das relações entre lëistér e o seu sinônimo posterior peiratés, ver: Pritchett, 1991, p. 316-8 e Souza, 1999, p. 1-12.
} 
não se encaixariam na elite da sociedade homérica. Trata-se, aqui, do relato (fictício, mas verossímil) que Odisseu/mendigo faz ao porqueiro Eumeu acerca de seu passado em Creta (xiv, 199-284). Nesse relato, o mendigo cretense - filho de um homem rico e de uma escrava, preterido pelos irmãos na divisão da herança do pai, mas que obteve um casamento vantajoso devido ao seu valor (areté) - relata com orgulho como a sua capacidade guerreira (apta para planejar emboscadas, lokhoí) lhe permitiu liderar nove expedições de saque contra homens de outras terras, antes de embarcar para Troia como um dos líderes do contingente cretense e de se aventurar em mais uma expedição de razia contra o Egito. E relata ainda como o sucesso em tais empreendimentos, e o consequente enriquecimento do seu domínio (ổkos), o tornaram temido e respeitado (deinós t' aidoî́s te, v. 234) entre os cretenses. ${ }^{3}$

Neste texto, pretendo explorar um dos tipos mais comuns de razia presentes nos poemas homéricos, a razia de gado, tomando como ponto de partida um ataque no qual o próprio Nestor atuou como lëistér, como saqueador. Trata-se do episódio de "roubo de

${ }^{3}$ Conferir também o passo no qual Odisseu afirma que pretende repor parte das reses consumidas pelos pretendentes por meio de saques praticados por ele mesmo $(\mu \tilde{\eta} \lambda \alpha[\ldots] / \pi \mathrm{o} \lambda \lambda \dot{\alpha} \mu \dot{\varepsilon} v \alpha \hat{v} \tau$ ò $\varsigma \dot{\varepsilon} \gamma \grave{\omega}$ $\lambda \eta \hat{i} \sigma \sigma o \mu \alpha 1$, xxiii, 356-7). Na Ilíada, por outro lado, é o próprio Aquiles quem rememora o fato de já ter saqueado vinte e três cidades da Tróade, por mar e por terra, e de ter tomado, de todas elas, "muitos

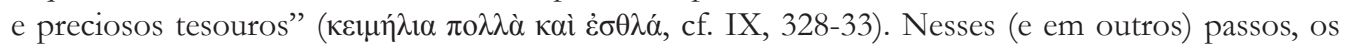
mesmos personagens homéricos aparecem envolvidos em atividades bélicas que poderiam ser descritas como: a) campanhas ad hoc (talvez) relacionadas ao conflito intercomunitário troiano, tais como as expedições de saque de Nestor e Aquiles na Tróade; b) empreendimentos privados de obtenção de butim, como as nove razias mencionadas do Odisseu/cretense, a sua expedição final contra o Egito e as planejadas razias de Odisseu para a reposição do seu rebanho; c) atividades bélicas indeterminadas, como o saque de Odisseu a Ísmaros (ix, 37-166) - uma última escaramuça contra aliados troianos (cf. II, 846) ou uma agressão não provocada com o único objetivo de angariar butim? Essa versatilidade de engajamento dos personagens homéricos em atos bélicos que um leitor moderno entenderia como bastante distintos (e até antagônicos) sugere que é temerário traçar uma divisão rígida entre, de um lado, saqueadores profissionais interessados apenas em obter butim de forma privada - os únicos que poderiam ser chamados de lë̈stêres, termo que implicaria uma conotação negativa - e, do outro, heróis envolvidos em atos bélicos comunitários, motivados por questões de honra e apenas ocasionalmente interessados em saque privado. Diante da evidência disponível, a posição mais prudente talvez seja admitir que todo herói homérico é também um lëistér em potencial e pode ser assim descrito por outro personagem sem implicar um ato de crítica, como indicaria a naturalidade do questionamento de Nestor. Tal posição se alinha à tese de van Wees (1992, p. 167-217 e 244-51) acerca da existência de dois tipos de conflito bélico (warfare) nos poemas homéricos (ambos legítimos, ambos praticados pelos mesmos atores e, portanto, de difícil diferenciação): um primeiro tipo, predatory warfare, envolvendo a mobilização privada de combatentes para a aquisição de butim; enquanto o segundo, status warfare, envolvendo a mobilização pública (autorizada ou sancionada pelo dêmos de uma dada comunidade) desses mesmos combatentes para atuarem em conflitos cujo pano de fundo é a competição por status entre comunidades. Vale ressaltar que as atividades que serão objeto de comentários neste texto - o roubo de gado e o emprego de emboscadas - podem figurar em ambos os tipos de conflito bélico discutidos acima (cf. van Wees, op. cit., p. 213), razão pela qual a distinção entre eles não será enfatizada na argumentação. 
gado" (boèlasía) seguido por uma batalha campal que o velho líder pílio narra a Pátroclo, a título de exortação, quando este se dirige a sua tenda, a mando de Aquiles, para confirmar a identidade de um herói ferido (XI, 668-762). ${ }^{4}$

Segundo o ancião, quando era jovem e ainda inexperiente na guerra, ele havia praticado uma razia contra um povo vizinho (os epeios), durante a qual reuniu um enorme espólio (lếis, v. 677) que incluía numerosos rebanhos de bois, de ovelhas e de cabras, varas de porcos, manadas de éguas com seus potros e, ainda, alguns pastores (v. 677-81 e 697). Esse vasto conjunto de animais (e escravos) - que, apesar de sua diversidade, foi obtido em uma ação caracterizada pelo próprio Nestor, de forma genérica, como boēlasía (v. 763) - foi tomado em represália às várias agressões cometidas pelos epeios contra os pílios. ${ }^{5}$ Ainda segundo Nestor, sua boèlasía teve como resposta um ataque retaliatório dos epeios contra parte do território pílio. Nesse combate, o jovem herói teve um papel preponderante, embora participasse da batalha em desvantagem e contra a vontade de Neleu, que havia escondido sua carruagem na esperança de impedi-lo de lutar. Nestor, então, mesmo lutando como um peão, colocou-se entre os combatentes dianteiros, tomou a carruagem de sua primeira vítima, o campeão inimigo Múlio, e liderou a vitória do exército pílio, matando nada menos do que cento e um guerreiros (v. 717-66).

O curto relato de roubo de gado de Nestor não é um evento único em Homero ou na tradição épica grega. De fato, na Ilíada e na Odisseia, assim como no restante do corpus conservado do épos arcaico, existem frequentes referências (geralmente de forma bastante breve e concisa) a episódios de razia de gado. É nesse contexto que devem ser compreendidas, por exemplo, as (já mencionadas) palavras de Odisseu, quando o herói afirma a Penélope que ele reporá os rebanhos consumidos pelos pretendentes por meio de dádivas que lhe serão ofertadas pelos itacenses e mediante razias praticadas por ele mesmo (xxiii, 356-8). A mesma naturalidade em relação à prática da razia de gado aparece quando Aquiles, no episódio da embaixada, caracteriza bois e rebanhos como lë̈stoí, "adquiríveis por saque" (IX, 406).

Nesses e em outros testemunhos, a apropriação violenta de gado é retratada como uma importante atividade do mundo representado nos poemas homéricos e em boa parte do restante épos arcaico, qualquer que seja a relação entre tal representação e a realidade histórica. Na verdade, se comparado ao furto de escravas ou de keimélia (objetos preciosos entesouráveis), o furto de animais assume uma importância especial, dado o duplo papel

\footnotetext{
${ }^{4}$ Boèlasía, um hápax legómenon homérico traduzido pelo LSJ como “driving of oxen, cattle-lifting” e composto a partir da combinação entre boûs (boi) e elaúnō (impelir), significaria 'tocar bois' (como butim), cf. também Chantraine, 1968-77, s.v. leía, boûs, elaúnō. Na falta de um termo único na épica arcaica para roubo de animais em geral (o substantivo lêtis e o verbo cognato lếisdomai podem ser empregados para animais, pessoas e coisas) e diante da aplicação genérica de boēlasía a ser comentada, entenderei esse termo como roubo de gado em geral, incluindo bois, cabras, carneiros, porcos, etc., mas também cavalos e mulas.

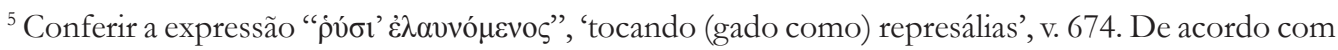
Hainsworth, 1993, ad v. 674, p. 299, rbýsia, outro exemplo de hápax legómenon homérico, seriam "pledges seized as surety for repayments, or simply booty seized in reprisal".
} 
desempenhado pelo gado como elemento propiciador de subsistência e como o principal símbolo de riqueza nas representações mitopoéticas de uma cultura de substrato indoeuropeu, cuja mentalidade foi moldada (em grande parte) pela prática pastoril. ${ }^{6}$

O roubo de gado constitui, portanto, um elemento recorrente e tradicional na poesia homérica e no restante da épica grega arcaica, e esse ato é muitas vezes apresentado como algo natural e proveitoso para os personagens. Mas, se essa atividade é tradicional, como ela é efetivada no texto homérico em termos de dicção e associações de ideias e procedimentos narrativos típicos? Quais seriam os elementos tradicionais presentes, por exemplo, no conciso episódio da razia de gado relatada por Nestor a Pátroclo?

\section{A macroestrutura do Relato: RaZia Campestre E batalHa NaS CERCANias DE UMA PÓLIS}

Para fornecer uma resposta a esse questionamento, é preciso, antes de mais nada, observar a estrutura geral do episódio. O relato de Nestor acerca do neîkos entre pílios e epeios (XI, 670-761) é estruturado na forma de um díptico, uma composição em dois blocos. ${ }^{7} \mathrm{O}$ primeiro desses blocos principia com um recurso comum a outras recordações paradigmáticas do mesmo ancião, uma expressão de nostalgia pela sua juventude perdida (v. 670), e é centrado na narração da razia de gado em si (v. 670-84) e na divisão do butim resultante em Pilo (v. 685-8; 696-8; 703-5). Ainda neste bloco, encaixada entre os versos que descrevem a divisão da pilhagem, está a rememoração das causas mais remotas e das razões imediatas que motivaram a ação: o enfraquecimento dos pílios como consequência do ataque de Héracles a Pilo (v. 689-93), a arrogância e sobranceria oportunistas dos epeios e as consequentes agressões cometidas por eles contra vários dos pílios (v. 694-5) e por

\footnotetext{
${ }^{6}$ A esse respeito, veja-se o passo da Odisseia em que Eumeu detalha a imensa riqueza de Odisseu em termos de bois, ovelhas, porcos e cabras (xiv, 99-104, 107), que cito agora: “[...] Mas eu, para ti, enumerarei tudo./ No continente, doze boiadas, tantos rebanhos de ovelhas, / tantas varas de porcos, tantos vastos rebanhos de cabras,/ tudo isso vigiam pastores estrangeiros e do seu próprio povo./ Aqui dentro, os vastos rebanhos de cabras, todos os onze,/ pastam nos confins, sob os cuidados de homens nobres./ (...) Mas eu vigio e protejo estas porcas aqui [...] ([...] $\dot{\varepsilon} \gamma \grave{\omega} \delta \varepsilon \dot{\varepsilon} \kappa \varepsilon \dot{\varepsilon} \tau \mathrm{cot} \kappa \alpha \tau \alpha \lambda \dot{\varepsilon} \xi \omega . / \delta \omega ́ \delta \varepsilon \kappa '$

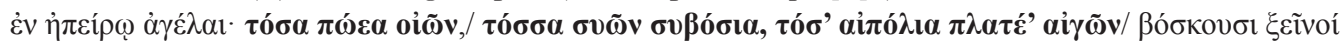

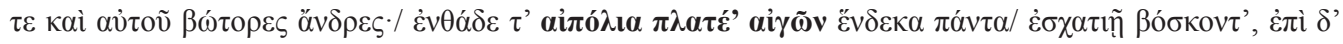

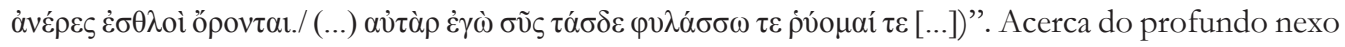
entre gado e riqueza na cultura indo-europeia, conforme atestado, e.g., no grego próbata e no latim pecu e pecunia, ver Benveniste, 1995 [1969], p. 35-58. Para a prática extensiva do pastorialismo como uma das atividades definidoras da elite homérica e para o papel do gado como meio de subsistência e como principal símbolo de riqueza (seja na sua função de parâmetro de valor, seja como elemento essencial nas atividades relacionadas à atribuição de estima social dentro e fora de uma comunidade), ver: Donlan, 1997, p. 654-5 e 663-5.

${ }^{7}$ Cf. Martin, 2003, p. 62.
} 
Augias contra Neleu (v. 699-702). ${ }^{8}$ Para permitir um melhor acompanhamento da exposição, forneço aqui uma tradução do passo em questão (XI, 670-705):

Quisera eu fosse jovem, e o meu vigor firme

como quando entre os eleios e nós surgiu um conflito

por causa de um roubo de gado. Quando matei Itimoneu,

nobre filho de Hipíroco, que vivia na Élide,

ao tomar gado em represália. Ele, ao guardar seus bois,

foi atingido entre os dianteiros por um dardo que partiu de minha mão

675

e tombou. E o (seu) povo campônio fugiu em redor.

Mas nós reunimos, da planície, um imenso butim:

cinquenta rebanhos de bois, tantos rebanhos de ovelhas,

tantas varas de porcos, tantos vastos rebanhos de cabras,

cento e cinquenta bestas baias -

todas fêmeas, muitas com potros embaixo.

E tudo isso tocamos para dentro de Pilo Neleia, de noite, (tomando) a direção da cidade. E Neleu alegrou-se em suas entranhas porque a mim, que fora novo para o combate, couberam muitas coisas.

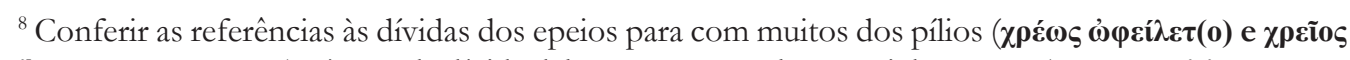

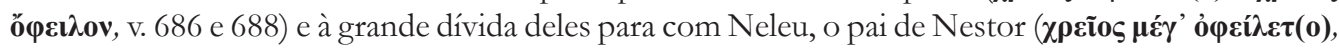
698). Nesse último caso, o ato que gerou tal dívida é especificado: o líder dos epeios, Augias, se apoderou de quatro cavalos (e do respectivo carro) que pertenciam a Neleu e que haviam sido enviados à Élide para participarem de uma competição (v. 698-702). Não satisfeito, Augias também enviou de volta para Neleu o auriga pílio dos cavalos (em lugar de escravizá-lo, como os próprios pílios fizeram posteriormente com os pastores capturados por Nestor), talvez para contar o ocorrido (cf. a referência aos épea que encolerizaram Neleu no v. 703). Tal comportamento do líder epeio sugere, como observou van Wees (op. cit., p. 196), um ato de insulto calculado que é condizente com a explicação de Nestor para as causas mais remotas da contenda: a arrogância e sobranceria dos epeios (cf. hyperēphanéontes/ bybrísdontes Epeioí, v. 693-4), que procuravam afirmar sua superioridade à custa dos vizinhos em um momento em que Pilo estava enfraquecida como resultado de um conflito anterior com Héracles (cf. 689-95). As motivações e a dinâmica do neîkos entre os pílios e os epeios se adequam, portanto, a um padrão comum nos poemas homéricos: o desenvolvimento de um confronto intercomunitário a partir de conflitos privados entre membros da elite de duas ou mais comunidades. No caso em questão, para além do episódio relativo aos cavalos de Neleu (um roubo de animais, afinal), é possível supor que as mencionadas dívidas dos outros epeios para com os pílios também poderiam ser entendidas como resultantes de razias privadas de gado. Um elemento que suporta essa hipótese é o fato de a combinação entre o substantivo khreîos e o verbo ophéllō, apontada acima, reaparecer no contexto de uma embaixada de Odisseu (como representante de sua comunidade) para recuperar gado roubado

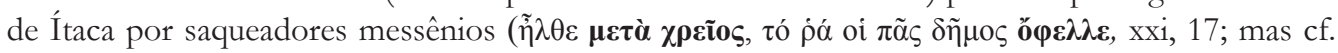
também iii, 367). De qualquer modo, o fato essencial é que as ofensas privadas dos epeios motivaram uma retaliação pública por parte dos pílios na forma do ataque aos numerosos rebanhos de um rico

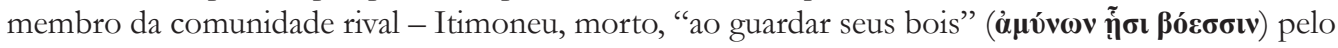
jovem Nestor, cf. v. 672-5. 
E com o nascer da aurora, arautos começaram a clamar para virem aqueles aos quais uma dívida era devida na Élide divina.

E os líderes dos pílios, após se reunirem, começaram a fazer a partilha, pois a muitos os epeios deviam

já que nós, em Pilo, éramos poucos e oprimidos.

[uma dívida,

É que, após ter ido para lá, a força de Héracles nos afligiu

em anos anteriores, e quantos eram os melhores foram mortos.

Pois doze éramos nós, os filhos do excelente Neleu, dos quais eu, sozinho, sobrei; os outros todos foram mortos.

Tornando-se arrogantes por causa disso, os epeios cobertos de bronze começaram a tramar atos soberbos, nos ultrajando.

Do butim, o velho Neleu uma manada de bois e um grande rebanho [de ovelhas tomou, tendo escolhido trezentas com seus pastores. É que também para ele uma grande dívida era devida na Élide divina: quatro cavalos ganhadores de prêmios, com o respectivo carro, que tinham ido para competições, pois por uma trípode iam correr. Esses, Augias, soberano de homens, lá os reteve; mas mandou embora o auriga, afligido pelos cavalos. Agastado com essas coisas, palavras e atos, o velho reservou para si incontáveis (reses). O restante deu ao povo para distribuir, para que ninguém fosse embora privado de parcela [adequada.

Quanto ao segundo bloco (v. 706-61), ele engloba, em ordem cronológica: o cerco do exército epeio à Trioessa, junto ao rio Alfeu, na fronteira do território de Pilo (dia 3); o aviso noturno de Atena aos pílios e a concentração do exército pílio junto ao rio Minieio (dia 3, noite); a marcha dos pílios até a região do combate campal e a sua preparação para o mesmo (dia 4); e a batalha campal, englobando os feitos de Nestor e a derrota e fuga dos epeios para fora da região de Pilo (dia 5). ${ }^{?}$

Como mostra essa rápida análise da estrutura geral do episódio, cada um dos blocos do relato de Nestor tem no seu centro uma narrativa de combate. A primeira delas toma a forma de uma breve escaramuça na qual um grupo de atacantes (cujo número não é especificado) investe contra os numerosos animais guardados por Itimoneu e por um grupo de pastores. O caráter campestre dessa escaramuça, já evidente na referência ao vasto número de reses, é reforçado pela aplicação do termo agroiótēs, "campônio", aos pastores (v. 676). ${ }^{10}$

\footnotetext{
${ }_{9}^{9}$ Assim como no primeiro bloco (cf. v. 670 e v. 684), também no segundo a juventude e a inexperiência de Nestor são enfatizadas, agora mediante a indicação de que seu pai não desejava que ele participasse do iminente combate: “[...] mas Neleu não/ permitia que eu me armasse e escondeu meus cavalos,/ pois dizia que eu não conhecia nada ainda dos trabalhos de guerra" (v. 717-9).

${ }_{10}$ Trata-se de um termo que ocorre mais cinco vezes no conjunto restante da épica grega arcaica, a saber: XI, 549 (símile: cães e homens campônios, anéres agroiôtai, repelem o ataque noturno de um
} 
Quanto ao segundo, trata-se de uma versão reduzida da batalha campal entre dois exércitos, geralmente nas cercanias de uma pólis, que é tão familiar ao público da Ilíada.

Ainda acerca da macroestrutura do relato, é necessário observar que essa mesma justaposição de dois tipos de combate também ocorre em outras passagens dos poemas homéricos, embora nem sempre de modo tão desenvolvido como no relato de Nestor. Dentre essas passagens, o exemplo mais importante é aquele da representação da cidade em conflito na écfrase iliádica do escudo de Aquiles (XVIII, 509-40).

No referido passo, os habitantes de uma cidade cercada por dois batalhões de inimigos, após recusarem uma proposta de rendição, aproveitam um momento de distração dos seus atacantes (que estavam reunidos em assembleia) para montar uma emboscada contra os mesmos (cf. lókhos, v. 513). Essa emboscada toma a forma de uma razia contra o gado dos sitiantes, cujos pastores são mortos e os animais cercados junto a um rio, em uma aguada. ${ }^{11}$ Nesta razia, ao contrário do que acontece naquela do (então) jovem herói pílio, a ação de pilhagem não chega a ser consumada, pois o "grande clamor de junto dos bois" (v. 530) alerta os sitiantes, que abandonam a sua assembleia e se dirigem ao encontro dos inimigos. Na sequência, a emboscada/razia de gado dá, então, lugar a uma feroz e sangrenta batalha campal junto aos bancos do rio (v. 533-40).

Outro exemplo de razia campestre (também interrompida) que dá lugar a uma batalha campal retaliatória é a fictícia (e funesta) expedição contra o Egito capitaneada por Odisseu/ cretense. Em ambas as formas desse logro - narradas pelo mendigo para Eumeu (xiv, 24384) e Antínoo (xvii, 424-44) - os companheiros de tropa desobedecem a orientação de seu comandante, que preferia uma abordagem mais cautelosa e furtiva, e começam a devastar abertamente os belíssimos campos dos egípcios. ${ }^{12}$ Como resultado, os habitantes de uma

leão a um estábulo de bois); XV, 272 (símile: cães e homens campônios, anéres agroiotai, perseguem um veado ou uma cabra selvagem); xi, 293 (seção dedicada à esposa de Neleu, Cloris, e à sua descendência no catálogo das heroínas: Melampo - o adivinho que fora enviado por Nestor para roubar o gado de Íficles e assim obter a mão da filha do líder pílio, Peró, para seu irmão Bias - é tolhido por dolorosas cordas e por boieiros campestres, bonkóloi agroiôtai); xxi, 85 (prova do arco: Eumeu e Filécio, os fiéis porqueiro e boieiro de Odisseu, são chamados de tolos campônios, népioi agroiôtai, pelo pretendente Antínoo); Scutum, 39 (Anfitrião, acabada a sua expedição contra os Táfios e Telebóas, dirige-se para junto de sua esposa, sem visitar primeiro seus escravos e pastores do campo, poiménes agroiôtai). A pesquisa das ocorrências dos termos e fórmulas no corpus da épica arcaica foi feita mediante consulta às edições e aos comentários impressos e aos bancos de textos digitais dos projetos Thesaurus Linguae Graecae e The Chicago Homer (referidos na bibliografia).

11 "Ao vê-los adiante, eles (os emboscadores) assaltaram. Em seguida, logo/ começaram a cortar o acesso às boiadas e aos belos rebanhos/ de alvas ovelhas, e também matavam os pastores (oî $\mu \dot{\varepsilon} v$

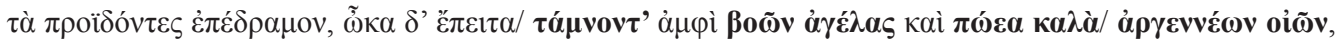

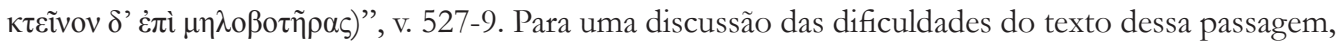
cf. Edwards, 1991, p. 218-21.

12 "Então eu ordenei aos fiéis companheiros/ que lá, junto das naus, permanecessem, as guardando,/ e despachei vigias para se postarem nas atalaias./ Mas eles, após cederem à presunção e se entregarem ao seu ardor,/ bem rapidamente os belíssimos campos ( $\pi \varepsilon \rho \iota \kappa \alpha \lambda \lambda \varepsilon \dot{\varepsilon} \alpha \varsigma$ $\alpha \gamma \rho o u ́ \varsigma)$ dos homens egípcios / 
cidade das redondezas, alertados pelo clamor das vítimas, preparam durante a noite uma expedição retaliatória que alcança os saqueadores no princípio do outro dia e os massacra em uma batalha campal.

Além da narrativa de Nestor (que se estende por noventa e um versos), do trecho do escudo de Aquiles (com trinta e dois versos) e das duas passagens mencionadas acima (que variam entre vinte e trinta versos), as outras instâncias de justaposição entre combate campestre e batalha campal em Homero são bastante curtas, em geral ocorrendo na forma de brevíssimas alusões, por parte dos personagens, a eventos passados, tal como as referências de Andrômaca acerca do ataque de Aquiles contra sua cidade natal, Tebas-sob-Placo, e as recordações de Eneias e do próprio Aquiles acerca da expedição desse mesmo herói contra Linerso e Pédaso.

No primeiro caso (VI, 413-28), trata-se de uma sintética recordação de Andrômaca acerca dos sofrimentos que Aquiles já lhe havia imposto: a perda de seu pai durante o assalto daquele herói contra Tebas, a captura de sua mãe como presa de guerra no curso do mesmo evento e o massacre dos seus sete irmãos durante o que parece ser uma razia de gado. ${ }^{13} \mathrm{~A}$ natureza concisa dessa recordação, cujo estilo se assemelha ao de um catálogo, ${ }^{14}$ não permite entrever uma cronologia clara para os eventos, mas é possível inferir que, tal como nos outros episódios comentados, o ataque campestre contra os irmãos de Andrômaca seria tradicionalmente concebido como um ato prévio em relação à batalha campal diante dos muros de Tebas. De qualquer modo, essa é a ordem dos eventos presente nas recordações de Eneias (XX, 86-102) e do próprio Aquiles (XX, 178-94) acerca de seu encontro anterior no Monte Ida: um ataque campestre contra as reses de um pastor solitário, seguido do cerco e da destruição de uma pólis. ${ }^{15}$

começaram a devastar, e arrebatavam mulheres e criancinhas/ e matavam os homens. E logo a gritaria chegou à cidade", xiv, 259-65 = xvii, 428-34.

13 “"...] Não existem mais para mim um pai e uma veneranda mãe./ Pois o divino Aquiles matou meu

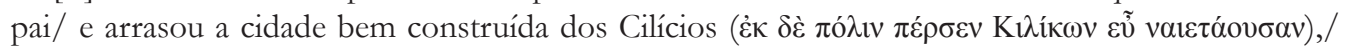
Tebas de altos portões [...]/. E os sete irmãos que eu tinha em casa, / todos eles foram para a mansão de Hades em um único dia,/ pois a todos matou o divo Aquiles de pés velozes/ junto aos (seus) bois

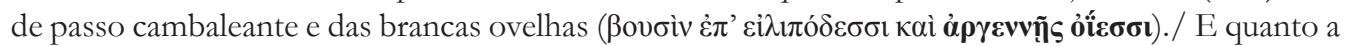
minha mãe - que fora rainha sob o Placo frondoso - / após tê-la trazido para cá com outras posses, / ele de novo a libertou, tendo recebido um incontável resgate./ Mas Ártemis frecheira a abateu no palácio de seu pai.", VI, 413-15, 421-28. Para outras referências do ataque de Aquiles a Tebas, cf. I, 366-9 (com menção à Criseida como parte do butim); IX, 186-9 (menção a uma lira como parte do butim); XVI, 153 (ao cavalo Pédaso como parte do butim); XXIII, 826-9 (a um lingote de ferro como parte do butim).

${ }^{14}$ Cf. Graziosi e Haubold, 2010, ad VI, 421-4.

${ }^{15}$ Eneias: "pois agora não é a primeira vez que contra Aquiles de pés velozes/ eu me oporei, mas já outrora ele me afugentou, com sua lança,/ para fora do Ida, quando atacou nossas vacas ( $\dot{\varepsilon} \xi$ ”I I $\eta \zeta$,

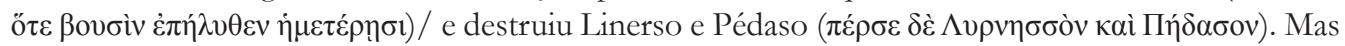
Zeus me/ protegeu [...]", XX, 89-93. Aquiles (em discurso para Eneias): "afirmo que já te afugentei outrora com minha lança./ Ou não te lembras quando, a ti que estavas só, para longe dos bois 
Em todos os cinco episódios comentados acima, a razia campestre e a batalha campal nas cercanias de uma pólis figuram como ações imbricadas - na medida em que a primeira é muitas vezes apresentada com uma causa ou como um evento anterior em relação à segunda - mas distintas. Dada a natureza dos poemas homéricos (e dos restantes testemunhos da épica arcaica) como textos derivados de uma tradição de poesia oral ${ }^{16}$ - na qual atividades recorrentes tendem a ser descritas, em maior ou menor grau, por meio de padrões narrativos e fraseologia recorrentes - é razoável supor que esses dois atos (a razia campestre e a batalha campal nas cercanias de uma pólis) podem ser descritos, do ponto de vista compositivo, como dois elementos (ou temas) distintos do sistema poético homérico. ${ }^{17}$

Tal hipótese é reforçada pelo fato de essas mesmas ações também figurarem como alternativas no corpus da poesia homérica. Esse é o caso de três passagens da Odisseia nas quais um personagem questiona seu interlocutor acerca dos acontecimentos que causaram a sua atual condição de infortúnio.

$\mathrm{Na}$ primeira delas, Odisseu pergunta à psykhé de Agamenão a razão da morte desse herói, durante a série de encontros entre o itacense e seus camaradas do cerco troiano no episódio da primeira nékyia (XI, 398-403). ${ }^{18}$ No passo em questão, o herói itacense imagina três possibilidades para o fim do filho de Atreu: morte no mar, morte em terra durante uma razia de gado ou morte em terra durante o cerco e destruição de uma pólis. Posteriormente, uma outra versão (ou multiforma) dessa pequena lista (temática) de "formas de morrer" que não inclui a forma sinistra e desonrosa por meio da qual o próprio Agamenão foi morto

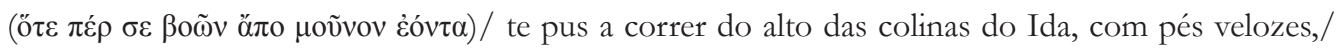
em debandada? Nessa ocasião, fugindo, não viraste para trás./ De lá fugiste para Lirnesso. Mas eu a cidade/ destruí ( $\pi \dot{\varepsilon} \rho \sigma \alpha)$, após me lançar para lá, com a ajuda de Atena e de Zeus pai/ e, depois de

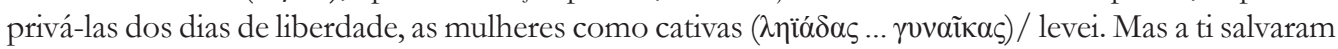
Zeus e os outros deuses.", XX, 187-94.

16 "Oral derived" ou "oral connected texts", conforme a nomenclatura cunhada por John M. Foley para indicar textos cujos elementos formadores são tidos em grande parte como originários de tradições que operavam por meio da composição, exposição e transmissão oral, mas cujos efetivos processos de criação, exposição e transmissão não podem ser identificados como totalmente orais (ou escritos). Para "oral derived”, cf. Foley, 1997, p. 162; para "oral connected”, Foley, 1999, p. xiv.

${ }^{17}$ Entendo "tema" na forma proposta por Albert Lord, como: "a recurrent element of narration or description in traditional oral poetry" e "a group of ideas regularly used in telling a tale in the formulaic style of traditional song”, cf. Lord, 1951, p. 73 e 2000 [1960], p. 68. Para os poemas homéricos (e talvez a épica grega arcaica como um todo) como "a system of interconnected poetic and cultural associations", cf. Dué e Ebbott, 2010, p. 16.

18 "Qual sina de morte dolorosa te subjugou?/ Acaso Posidão te subjugou nos navios,/ após incitar o violento sopro dos ventos terríveis,/ ou homens hostis te feriram em terra,/ quando tu (lhes)

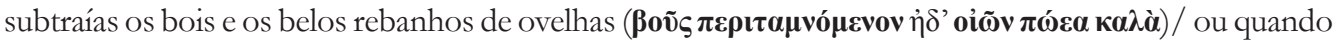
lutavas por uma cidade e por mulheres?” Notar a sobreposição de dicção formular entre o verso que

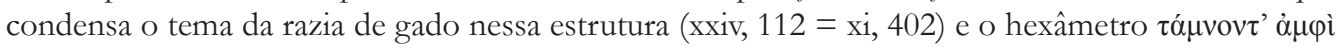

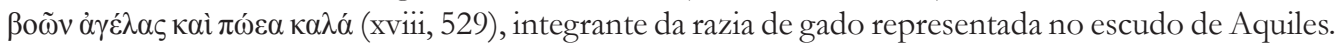


- é utilizada pela psykehé do próprio filho de Atreu para questionar aquela do pretendente Anfimedonte, durante a segunda nékyia do poema (xxiv, 109-13).

Quanto ao terceiro passo, trata-se de uma indagação do Odisseu/cretense acerca do passado do porqueiro Eumeu (xv, 381-8). ${ }^{19}$ Nesse trecho, a condição atual do fiel escravo (por nascimento, um membro da elite da ilha de Síria) é potencialmente explicada como o resultado ou da destruição da pólis (paterna) ou de um ataque campestre a um pastor solitário e a suas reses. ${ }^{20}$ Embora nenhuma dessas duas alternativas corresponda à real história de vida de Eumeu (raptado por comerciantes fenícios em conluio com sua ama, uma escrava também originária da Fenícia), a segunda delas é bastante próxima daquela de sua raptora: a filha de um homem rico que havia sido raptada, ao voltar do campo (agróthen, v. 428), por saqueadores táfios e, depois, vendida ao ôkkos de Laerte (xv, 390-484).

Em suma, por meio dos vários episódios e trechos elencados, é possível atestar a existência, na poesia homérica, de estruturas temáticas referentes a dois tipos ou situações de combate distintas, ora apresentadas como complementares ora como alternativas. As características específicas (observadas até agora) de cada uma dessas situações podem ser organizadas conforme o quadro abaixo: ${ }^{.1}$

\footnotetext{
19 "Ai, como eras jovem, porqueiro Eumeu,/ quando foste levado para bem longe da tua pátria e de teus pais!/ Mas vamos, me diga isto e me conte em detalhes:/ acaso foi arrasada a cidade de amplas ruas/ na qual viviam teu pai e tua veneranda mãe/ ou a ti, que havia sido deixado só junto às ovelhas

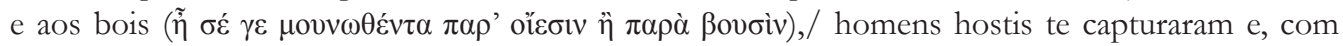
navios, te venderam/ para a casa desse homem, que (por ti) pagou um preço adequado?”, xv, 381-8. ${ }^{20}$ Como testemunha esse passo, a captura de pastores ou boieiros (sejam eles provenientes de famílias poderosas ou apenas servos/dependentes) também pode figurar como algo comum nos episódios de razia campestre - além, é claro, do roubo das próprias reses. A esse respeito, vale lembrar que a porção de honra (géras) escolhida por Neleu dentre o butim obtido por seu filho incluía, como vimos,

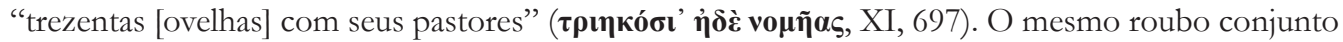
de pastores e ovelhas (indicado, aliás, pela mesma fórmula, que ocupa todo o segundo hemistíquio) ocorre de novo em uma referência à razia praticada pelos messênios contra os rebanhos de Ítaca (xxi, 15-21, cf. nota 8 supra). Por fim, na Iliada, uma brevíssima digressão do poeta nos informa que os heróis Iso e Antifo, dois filhos de Príamo mortos por Agamenão durante a sua aristeía, já haviam sido capturados antes por Aquiles, nas escarpas do Ida ('I $\delta \eta \varsigma$ Ẻv $\kappa v \eta \mu o \tilde{\sigma})$ ), "ao pastorearem as suas ovelhas" (poimainont' ep’ óessi) e depois soltos pelo mesmo herói mediante resgate (cf. XI, 106-11).

${ }^{21}$ Com ressalvas, devido à plasticidade e multiformidade características da poesia homérica. A esse respeito, convém lembrar a advertência de Kelly, 2007, p. 14: "the Homeric Kunstsprache is a living organism for its audience, and rigid structural categorization merely describe the poetry from a compositional rather than a semantic perspective".
} 


\section{QUADRO 1}

\begin{tabular}{|l|l|l|}
\hline Local & \multicolumn{1}{|c|}{ Razia ou combate campestre } & \multicolumn{1}{c|}{ Batalha campal } \\
\hline $\begin{array}{l}\text { Oponentes/ } \\
\text { vítimas }\end{array}$ & $\begin{array}{l}\text { pastores (jovens oriundos de famílias }{ }^{22} \text { locais de pastoreio } \\
\text { poderosas ou servos/dependentes } \\
\text { campônios) }\end{array}$ & $\begin{array}{l}\text { planície (pedion), cercanias imediatas de } \\
\text { uma pólis }\end{array}$ \\
\hline $\begin{array}{l}\text { Bens (ktếmata) } \\
\text { adquiridos }\end{array}$ & $\begin{array}{l}\text { principalmente gado, mas também inimigas } \\
\text { cavalos e (por vezes) escravos (pastores, } \\
\text { crianças, mulheres) }\end{array}$ & $\begin{array}{l}\text { keimélia, implementos de guerra, cavalos } \\
\text { e carros, escravos (crianças e mulheres - } \\
\text { oriundos de famílias da elite ou não) }\end{array}$ \\
\hline
\end{tabular}

O roubo de gado ou boèlasía surge, então, como uma atividade típica do combate campestre. $\mathrm{Na}$ verdade, se atentarmos para o fato de que a maior parte dos episódios de escaramuças no campo toma a forma de uma apropriação violenta de reses, seria mais correto dizer que esse ato é a principal atividade definidora dessa categoria, contrastando com a aquisição de keimélia ("tesouros", englobando artefatos de alto valor produzidos com

${ }^{22}$ Acerca das noções de "campo" e "campestre” em Homero, cf. Donlan, 1989, 129-45. Nesse artigo, Donlan efetua uma cuidadosa descrição do ambiente rural homérico, mostrando como seus vários segmentos se distinguem uns dos outros, dentre outros fatores, pela distância relativa ao núcleo "urbano" da comunidade (ásty ou pólis, no seu sentido mais restrito). De acordo com essa descrição (op. cit., p. 135-7), em sua maior parte dependente da Odisseia, o ambiente rural homérico poderia ser dividido em: a) pedíon ou "planície", terra chã cultivável, contigua à pólis e atravessada por uma estrada que parte do núcleo urbano; b) agrós(oí) ou "campo(s)", área cultivável (plana ou um pouco elevada) que se segue à "planície", mas que ainda está localizada a uma distância conveniente do centro urbano e ainda é acessível por uma estrada; c) agrồ eskhatié ou "borda do campo", parte do agrós mais afastada - de terreno bem mais acidentado e, portanto, de cultura mais trabalhosa - que constitui o limite da zona de cultivo; d) eskhatié, ou "borda", zona marginal para além das terras cultivadas, formada por encostas íngremes e por um terreno montanhoso e arborizado que constitui a fronteira da comunidade e que é habitada pelos animais selvagens. Nesse ambiente rural, a atividade de pastoreio (ou melhor, as grandes operações pastoris dos basileîs, as únicas mencionadas por Homero) ocuparia vastas áreas ainda não cultivadas (e, portanto, ainda não alocadas) do pedion e do agrós (em especial as "pradarias", leimônes, e as "zonas inundáveis nas proximidades dos rios", hélea, terrenos muito propícios para cavalos e bois, cf. iii, 421-2; iv, 600-8; XVIII, 574-86 e XX, 221-2), do agrồ eskhatie (cf. xiv, 1-20; xvi, 154-5 e 452-3 e xxiv, 149-50, para os porcos de Eumeu) e, também, a totalidade das encostas e do terreno montanhoso da eskhatie (para cabras, cf. xiv, 103-4; para bois e ovelhas, cf. as mencionadas razias de Aquiles contra as reses de Eneias e de Iso e Antifo e cf., ainda, XXI, 448-9 e Hino homérico a Hermes, 286-8). Ainda segundo Donlan (op. cit., p. 136, nota 26), apesar da existência desses vários segmentos, o termo agrós (e seus derivados) também portaria o sentido de "campo em geral" (“country"), ou seja: um espaço que se contrapõe à cidade tanto em termos geográficos como culturais. 
metais preciosos ou não, peças de metal não trabalhado e vestes suntuosas) por meio do cerco e destruição de cidades. ${ }^{23}$

Embora tais constatações pareçam óbvias - na medida em que apenas apontam para elementos derivados de uma organização e de um uso do espaço triviais em Homero, a saber: gado costuma ficar no campo e tesouros nas cidades - o mapeamento aqui efetuado dos elementos campestres da boèlasía (e a ênfase posta na sua contraposição à batalha campal nas cercanias de uma pólis) permitirá aproximar esse tema de outras atividades típicas que também acontecem em lugares isolados e que também são marcadas pelo confronto com oponentes despreparados na poesia homérica. Essa aproximação será efetuada nas seções seguintes, ao longo de uma exploração da dicção e dos padrões narrativos tradicionais presentes na boélasía de Nestor.

\section{DicÇão TRADICIONAL: RAZIA CAMPESTRE E SÍMILES}

Em relação à dicção e aos padrões narrativos, vários comentadores já observaram o fato de que a batalha campal do segundo bloco do relato de Nestor apresenta uma linguagem e estrutura típicas do combate ordinário iliádico, tomando a forma de uma aristeía condensada do (então) jovem líder pílio. ${ }^{24}$ Já o primeiro bloco, que é de fato o trecho que nos interessa aqui, foi muitas vezes tido como destoante em relação à narrativa principal do poema no qual está inserido e como mais próximo da Odisseia em termos de dicção. ${ }^{25}$

Com efeito, um rápido exame da linguagem do passo em questão revela que vários elementos dos versos que descrevem a razia e a divisão do butim em Pilo também ocorrem em contextos semelhantes no restante do corpus da épica arcaica, tais como: a) em contextos da Ilíada diversos da narrativa principal, como nas imagens de símiles que colocam em cena gado ou feras atacando gado e na representação da emboscada/boēlasía do escudo de Aquiles; b) em trechos da Odisseia relativos a gado, ao ambiente campestre em geral e a contextos de roubo de gado ou de distribuição de butim, tais como a descrição da riqueza de Odisseu feita por Eumeu, a referência ao ataque messênio contra os rebanhos de Ítaca e em passagens relacionadas ao roubo das ovelhas do Ciclope e das vacas de Hélio; c) em versos relativos ao butim de Hermes (as cinquenta vacas de Apolo) no extenso hino homérico dedicado a esse deus. ${ }^{26}$

\footnotetext{
${ }^{23}$ Acerca da natureza dos keimélia e do seu papel na troca ritualizada de dádivas no interior das elites homéricas, cf. Donlan, 1997, p. 663-5.

${ }^{24}$ Cf. Hainsworth, 1993, ad XI, 670-762 e Pedrick, 1983, p. 63-6.

${ }^{25}$ Cf. Martin, 2003, p. 51-65. Para os paralelos de dicção com a Odisseia, conferir os comentários de Hainsworth (1993, p. 296-302) e a nota seguinte.

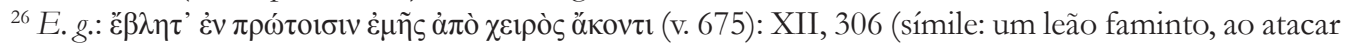
ovelhas em um redil, enfrenta a oposição de pastores e cães) || $\alpha \gamma \rho$ ot $\tilde{\tau} \alpha$ ( (v. 676): cf. nota 10 supra

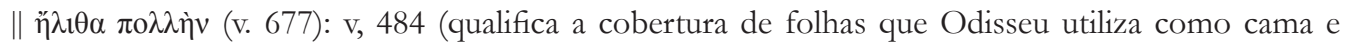
cobertor nos confins da Esquéria); ix, 330 (qualifica a cobertura de estrume sob a qual Odisseu esconde o cajado do Ciclope, após afiá-lo); xiv, 215 (aplicado ao substantivo dýe "infortúnio", durante
} 
Longe de serem apenas o resultado mecânico (e, portanto, destituído de significado específico) da economia formular típica do processo de composição oral, essas instâncias de sobreposição de dicção entre a boèlasía de Nestor e outros trechos do épos arcaico também relativos a episódios de roubo de gado, ou que colocam em cena gado, ou ainda que tematizam o ambiente campestre em geral, podem ser encaradas como indícios de que todos esses passos, na medida em que compartilham de uma mesma linguagem tradicional, também compartilhariam (em graus variados) de numerosas associações temáticas tradicionais. ${ }^{27}$

Em relação aos símiles, esses laços temáticos são bastante evidentes. De fato, o cenário de grande parte das imagens dos símiles (particularmente na Ilíada) é dominado pelo ambiente campestre frequentado pelo pastor e seus rebanhos, seja esse ambiente aquele das terras de pousio, dos prados e das zonas inundáveis nas proximidades dos cursos d'água

o primeiro relato da história de vida do Odisseu/cretense); xix, 443 (qualifica a camada de folhas sobre a toca do javali que fere o jovem Odisseu durante uma caçada no Parnaso \| $\boldsymbol{\pi} \boldsymbol{\varepsilon} \mathbf{v} \boldsymbol{\tau} \boldsymbol{\eta} \kappa \boldsymbol{\kappa} \boldsymbol{v} \boldsymbol{\tau} \boldsymbol{\alpha} \boldsymbol{\beta} \boldsymbol{\beta} \tilde{\boldsymbol{\omega}} \mathbf{v}$

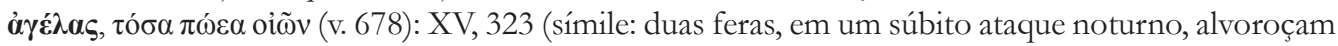
um rebanho de bois ou de ovelhas cujo pastor está ausente, cf. nota 49 infra); XVIII, 528 (cena de

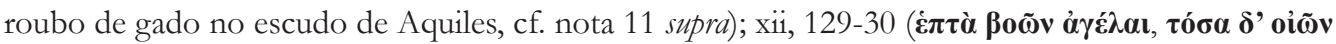

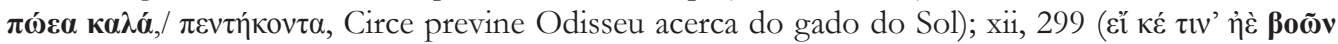

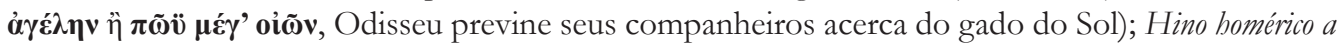

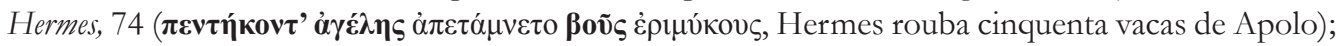

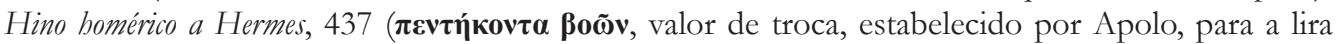

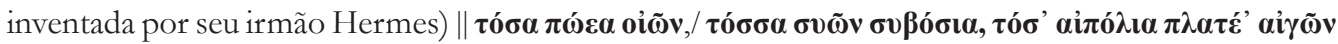

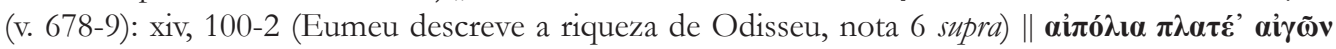
(v. 679): xiv, 102 e 103 (Eumeu descreve a riqueza de Odisseu); II, 474 (símile: comandantes aqueus organizam seus contingentes tão facilmente como cabreiros separam seus vastos rebanhos); Teogonia, 445 (Hermes e Hécate como divindades encarregadas do aumento ou diminuição de boiadas, de

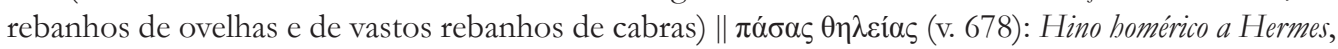

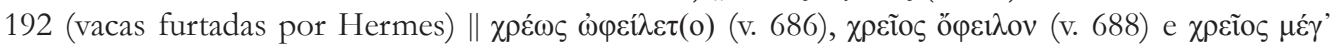

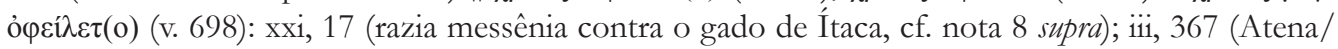

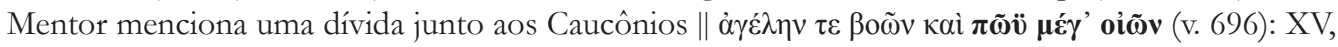

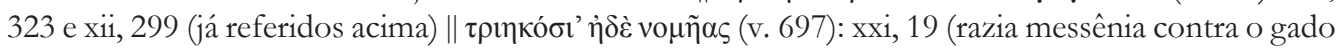

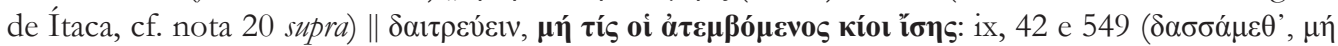

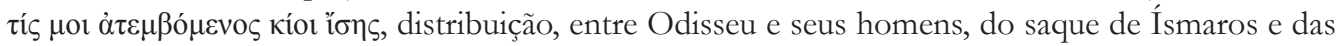
reses roubadas ao ciclope Polifemo).

${ }^{27}$ Tal raciocínio tem como pressuposto a indissociabilidade entre dicção e temas (ou seja, entre forma e conteúdo) no interior de uma dada tradição de poesia oral. Trata-se de um fenômeno já apontado, dentre outros, por Lord (2000 [1960], p. 22, 32 e 69) e explorado também por vários de seus continuadores. Dentre esses últimos, Nagy (1996, p. 22-3 e 1990, p. 29 e 31-2) é enfático em afirmar, acerca do épos grego arcaico, que é a dicção tradicional (i.e., as fórmulas) que está a serviço do conteúdo tradicional (i.e., os temas) - e não o contrário. Assim, tema e dicção estariam de tal modo interligados na dinâmica das tradições de poesia oral que a simples repetição de uma fórmula ou de uma estrutura formular semelhante no interior de um ou mais textos derivados de uma mesma tradição (como aqueles do épos grego arcaico) pode indicar que multiformas ou elementos de um mesmo tema estariam em operação nesses textos. 
(em suma, as terras baixas), seja aquele das colinas, das encostas e do terreno montanhoso e arborizado que marca a fronteira de uma dada comunidade. ${ }^{28}$ Nessas áreas isoladas, os pastores vivem uma existência marginal, tanto em comparação ao cotidiano dos habitantes do núcleo urbano, como em relação àquele dos ocupantes das pequenas glebas dedicadas à lavoura. Desprovidos de famílias, eles habitam abrigos transitórios (paradouros ou stathmoí) e dormem em cabanas. ${ }^{29}$ Além disso, estão sempre perambulando com os rebanhos que lhes foram confiados e ficam sempre sujeitos ao ataque daqueles que desejam a carne de suas reses, sejam estes outros homens ou, como é costumeiro nos símiles, as feras selvagens. ${ }^{30}$

Tal como nos episódios de razia campestre já comentados, também nos símiles a combinação entre o isolamento geográfico e social e a falta de vigilância ou (mesmo) a fraqueza e inépcia marcial dos pastores (e de seus cães) permite que as reses que eles guardam

${ }^{28}$ Conferir nota 22, supra, e, e.g, V, 136-43 (símile: pastor fere um leão que invade um aprisco, no agrós, para predar ovelhas); XV, 630-6 (símile: boieiro inexperiente não sabe como defender seu rebanho, que pasta ao longo de um héleos megáloio, de um "grande pântano", da investida de um leão) e XVI, 351-6 (símile: lobos predam anhos e cabritos que estão separados do rebanho, nas montanhas, devido à estultícia do pastor). Essa mesma divisão do espaço ocupado pela atividade de pastoreio em terras baixas e altas também aparece em uma vinheta dupla que integra a écfrase do escudo de Aquiles (XVIII, 573-86 e 587-9) e em um passo do Hino homérico a Hermes (v. 491-2). Acerca da prevalência do ambiente campestre da caça e do pastoreio nos símiles da Ilíada (e da sua ocorrência também na écfrase do escudo de Aquiles), cf. Redfield, 1994 [1975], p. 186-92 e Edwards, 1991, p. 34-7.

${ }^{29}$ Traduzo por "paradouro" (um regionalismo gaúcho para "lugar onde o gado manso costuma passar a noite", segundo o Dicionário Eletrônico Houaiss da Língua Portuguesa 3.0) o grego stathmós, glosado pelo LSJ como “standing-place for animals, farmstead, steading”. Para Knox (1971, p. 27-31), stathmós (em contexto campestre) designaria a totalidade de uma "estância" ou "rancho" dedicado apenas à atividade de pastoreio. Segundo essa autora (op. cit., p. 30), um estabelecimento pastoral como esse consistiria em uma "cabana", klisía, para os pastores (por vezes mais de uma é mencionada, cf. Hino homérico a Afrodite, 69 e 75), em um "pátio adjacente", aulé (também méssaulos), no qual os animais eram mantidos soltos ou em recintos, e (algumas vezes) também em uma área de pastagem cercada. Ainda segundo Knox, tais estabelecimentos deveriam ser visualizados como pequenos pontos de abrigo, entre os quais os pastores migrariam conforme as estações e a condição dos pastos.

${ }^{30}$ Cf. Redfield, 1994 [1975], 186-92 e Haubold, 2000, p. 17-20. Acerca do isolamento e marginalidade dos pastores, é útil conferir o que a Odisseia nos diz acerca das condições de vida de Filécio e Eumeu e compará-las com o que o poema afirma acerca do velho servo Dólio. Filécio vive fora de Ítaca, junto aos bois de seu mestre (cf. xx, 185-236); enquanto Eumeu habita um paradouro na borda do campo da ilha, dividindo com outros quatro pastores uma única cabana e o cuidado de cerca de novecentos e sessenta porcos (cf. xiv, 1-20 e 401-10; xvi, 154-5 e 452-3; xxiv, 149-50). Apesar da evidente prosperidade do estabelecimento que ele administra, o fiel porqueiro parece se ressentir da sua existência marginal, como mostra o seu anelo por "uma casa, um terreno e uma mulher muito cortejada" (xiv, 62-5, cf. também xxi, 207-16). Quanto ao velho Dólio, ele divide com seu recluso mestre Laertes (e juntamente com sua esposa e filhos, também servos) o cuidado da vinha e do pomar na bela quinta deste, localizada nas proximidades da pólis de Ítaca (xxiv, 205-7 e 384-411). Nessa propriedade, a família de servos e o seu recluso e entristecido senhor partilham não um abrigo ou um casebre temporário, mas uma casa de fato, um ổkos (cf. xxiv, 208, 358 e 365, cf. também dômata kalá no v. 361). 
se tornem alimento de predadores mais fortes ou mais habilidosos. Como sintetiza Johannes Haubold, em relação tanto aos símiles quanto à narrativa de ambos os poemas homéricos:

O fracasso do pastor é a norma, não a exceção. E se algumas passagens nos lembram que sem pastores as coisas poderiam ser ainda piores, isso apenas reforça nossa impressão de que o pastor, na épica arcaica, está no centro de um paradoxo: ele é indispensável, contudo ineficiente. É preciso que exista alguém que cuide dos rebanhos, mas, devido à natureza peculiar da sua tarefa, ele não pode ser bem-sucedido. ${ }^{31}$

Essa mesma presença distintiva do universo marginal povoado pelo pastor e seus rebanhos também pode explicar porque a dicção do primeiro bloco do relato de Nestor parece destoante em relação àquela empregada na narrativa principal da Ilíada e porque ela se assemelha mais àquela da Odisseia. Mais uma vez, o dado fundamental aqui é a forte ligação entre dicção e temas tradicionais: pois enquanto a narrativa principal do primeiro poema está concentrada nas interações que ocorrem no acampamento grego, na ásty troiana e na planície que separa essas duas comunidades, o cenário abarcado pelo relato principal da Odisseia é bem mais variado, apresentando uma ocorrência mais ampla de ações e situações ligadas ao ambiente pastoril.

De fato, na Ilíada, a ocorrência de pastores e rebanhos está em geral restrita a segmentos bem definidos em relação à narrativa principal, tais como: as descrições (e.g, as vinhetas da écfrase do escudo de Aquiles), os símiles e as várias histórias-encaixadas (embedded stories) narradas pelo poeta ou pelos seus personagens (categoria à qual pertencem a boèlasía de Nestor e as razias de gado praticadas por Aquiles). Na Odisseia, por outro lado, eles estão em toda a parte: nos símiles, nas descrições (e.g., a descrição do stathmós de Eumeu em xiv, 5-22), nas histórias-encaixadas (e.g, as referências à boèlasía praticada pelo adivinho Melampo, em ix, 281-97 e xv, 221-57), no longo relato de Odisseu aos feácios acerca das suas aventuras prévias (uma imensa história-encaixada, que inclui os episódios do roubo incidental das ovelhas de Polifemo e do roubo e consumo das vacas de Hélio), em outros elementos do discurso dos personagens (como os questionamentos de Odisseu acerca da morte de Agamenão e acerca do passado de seu porqueiro, abordados supra) e também em largas porções da narrativa principal (e.g, a longa narrativa da permanência de Odisseu/ mendigo junto a Eumeu).

Assim, a presença de um mesmo ambiente marginal frequentado pelo pastor e suas reses é um dos fatores que explica a sobreposição de dicção tradicional entre o sintético relato

31 "Failure of the shepherd is the rule, not the exception. If some passages remind us that without herdsmen things would be even worse, this can only strengthen our impression that the shepherd of early Greek epic stands at the centre of a paradox: he is indispensable and yet ineffective. There must be someone who looks after the flocks, but because of the peculiar nature of his task he cannot be successful", Haubold, 2000, p. 20. Para exemplos de símiles nos quais os pastores obtêm sucesso na defesa dos seus animais, ou nos quais o resultado final do embate não é indicado, conferir, e.g., X, 183-9; XI, 108-13; XI, 544-57; XVII, 657-77; XII, 299-308. 
iliádico da razia de gado praticada por Nestor, as imagens de símiles (sobretudo os iliádicos) que põem em cena o ataque de feras selvagens contra gado e vários passos da Odisseia. Tal conclusão é apenas o resultado da observação do nexo fundamental entre dicção e tema na dinâmica das tradições de poesia oral (e nos textos delas derivados) e sugere que tais passos, juntamente com a linguagem tradicional relativa a gado, também compartilhariam entre si numerosas e profundas associações temáticas correspondentes à representação das condições e dos perigos da atividade de pastoreio.

Ainda acerca da diferença entre a dicção da boēlasía de Nestor e o seu contexto iliádico, é proveitoso ressaltar, aqui, que a simples observação desse fato e do aspecto odisseico dessa dicção (sem a devida consideração das correlações temáticas subjacentes) levou a tentativas de explicar o relato do velho líder pílio como uma interpolação tardia inserida em uma estrutura iliádica anterior ou como o resultado da incorporação de material mitopoético derivado de uma saga regional. ${ }^{32}$

Essas soluções extratextuais - praticadas sobretudo pelos críticos analistas do século dezenove, mas também frequentes entre os homeristas da segunda metade do século vinte - foram combatidas por Richard Martin em um artigo seminal, no qual ele defende a aproximação da boēlasía de Nestor de uma outra porção da Ilíada que também foi (e ainda é) vista por muitos estudiosos como uma interpolação ou adição tardia e cuja dicção também é tida como semelhante àquela da Odisseia. Trata-se do conhecido episódio da Dolonia, a missão noturna de reconhecimento contra o acampamento troiano que ocupa a totalidade do décimo canto do poema. ${ }^{33} \mathrm{~A}$ esse respeito, a consideração de um estudo recente acerca da temática e do funcionamento da Dolonia - que inclui um furto incidental de cavalos pode ser proveitosa para a identificação de outros elementos tradicionais do roubo de gado de Nestor e do tema da razia campestre em geral. Passemos a ela.

\section{Padrões narrativos: razia campestre e emboscada}

Em Iliad 10 and the Poetics of Ambush, uma obra bastante influenciada pelo artigo de Richard Martin comentado acima, Casey Dué e Mary Ebbott procuram explicar a disparidade muitas vezes observada entre a Dolonia e o seu entorno iliádico, alegando que esse canto constituiria uma multiforma extensa de um importante tema tradicional do épos arcaico: o lókhos ou emboscada. ${ }^{34}$ Segundo essas autoras, apesar da existência de breves episódios e de menções a emboscadas no restante dos poemas homéricos e nos fragmentos do Ciclo Épico (e apesar de vários elementos associados a esse tema estarem presentes ao longo de toda a

\footnotetext{
32 Para um brevíssimo sumário da primeira posição, cf. Leaf, 1892, p. 213-4. Para uma defesa recente da antiga hipótese de que os conteúdos da narrativa de Nestor seriam derivados de uma antiga saga regional, cf. nota 43 infra.

${ }^{33}$ Cf. Martin, 2003, p. 43-65. Para uma pequena amostra dessa fortuna crítica acerca da Dolonia, cf. Leaf, 1892, p. 189-93, Willcock, 2009 [1978], p. 295, West, 2011, p. 233-4 e Hainsworth, 1993, p.151-5. Para um exame crítico detalhado desses posicionamentos, cf. Dué e Ebbott, 2010, p. 3-29.

${ }^{34}$ Cf. Dué e Ebbott, 2010, p. 31-87, para o conjunto dessa exposição.
} 
Odisseia), o único tratamento extenso conservado do tema seria a Dolonia, razão pela qual esse canto parece tão anômalo quando comparado ao restante dos textos de que dispomos.

Para Dué e Ebbott, o lókhos constituiria um tipo alternativo e complementar de poética da guerra, que se contraporia à modalidade de combate mais comum em Homero: a batalha diurna convencional entre campeões ou massas de guerreiros, chamada pelas autoras de pólemos. Os traços mais importantes dessa outra modalidade seriam a ação noturna e o emprego pronunciado da capacidade intelectiva da mêtis (astúcia, artifício), e a sua atividade mais representativa seria o ato de emboscada (lókhos). No entanto, advertem as autoras, o lókhos, na qualidade de "tema abrangente do combate alternativo" (overarching theme of alternative warfare), também poderia englobar outros tipos de combate não convencional, tais como missões de reconhecimento, razias noturnas em campo inimigo e - o que é fundamental para este texto - o roubo de gado. ${ }^{35}$ Tais ações, na qualidade de subtemas ou de temas estreitamente relacionados ao lókhos, poderiam compartilhar de algumas de suas características, dentre as quais: ${ }^{36}$

a) o cenário muitas vezes noturno, que favorece o ataque ou a ação surpresa;

b) o fato de o ato de lókhos ser muitas vezes representado como um tipo de recurso extremo, como uma maneira de resolver - pela ação furtiva, pelo planejamento e pela inteligência (indicados pelos termos mêtis, dólos, boulé e linguagem relacionada) - uma circunstância desesperadora ou de vencer um inimigo que não pode (ou não pôde) ser batido pelo enfretamento direto e aberto que tipifica o combate convencional (cuja qualidade fundamental seria a bié, força);

c) a representação dos participantes ou dos líderes (geralmente dois) do pequeno grupo de emboscadores como os melhores heróis (hoi áristoi);

d) a predileção pelo emprego (e a consequente descrição) de vestuário e armamentos que parecem inusitados, mas que são mais adequados para a ação noturna e furtiva, tais como implementos de peles de animais (que não refletem luz) e o arco - uma arma bastante adequada para a ação furtiva;

e) a ênfase na seleção ou na caracterização/descrição do local adequado para a ação de lókhos e a representação dos participantes em situações de tocaia e desconforto físico, e.g.: agachados na vegetação perto de uma estrada ou de um rio;

f) a representação do ataque surpresa como um rápido movimento dos emboscadores para fora do seu esconderijo e em direção às vítimas despreparadas (muitas vezes envolvidas em uma atividade pacífica).

Naturalmente, cada uma das características elencadas acima implicou, do ponto de vista diacrônico, o desenvolvimento de uma dicção e padrões narrativos típicos que, em um

\footnotetext{
${ }^{35}$ Dué e Ebbott, op. cit., p. 80-7 (87, para a citação).

${ }^{36}$ Cf. Dué e Ebbott, op. cit., p. 49-84.
} 
dado exemplo ou multiforma do tema em questão, podiam ser empregados por extenso (como no caso da Dolonia), figurar de forma bastante sintética ou até mesmo serem suprimidos. De qualquer modo, a simples presença, em um determinado passo, de vários elementos associados a essas características seria suficiente para indicar ao público que o tema da emboscada está em operação, mesmo que o termo lókhos não esteja presente. ${ }^{37} \mathrm{Na}$ mesma direção, a multiformidade inerente ao processo de composição e de recepção da poesia oral também permitiria que subtemas, procedimentos narrativos e dicção típicos dessa estrutura temática possam ser adaptados a contextos que não poderiam ser qualificados como lókhoi à primeira vista, tal como o episódio da embaixada de Príamo a Aquiles. ${ }^{38}$

Em relação ao relato do roubo de gado praticado por Nestor, a consideração desse episódio (e de outros exemplos de razia campestre) a partir do modelo proposto por Dué e Ebbott reforça a tese de uma forte relação entre boèlasía e lókhos, na medida em que permite entrever, mesmo em um texto tão conciso, a presença de vários dos elementos elencados acima.

O primeiro desses elementos é a possível natureza noturna da razia do filho de Neleu. Embora o velho rei pílio não especifique o momento preciso em que ocorreu a investida do seu provável bando (cf. os plurais synelássamen, v. 677, e elasámestha, v. 682) contra as numerosas reses de Itimoneu, ele indica que o butim foi conduzido para Pilo durante a noite por meio da aplicação, aos pílios, do adjetivo ennýkkb(i)os ("noturno", v. 683). ${ }^{39}$ Trata-se, aqui, de um adjetivo que ocorre mais seis vezes no restante do corpus hexamétrico arcaico, duas das quais em episódios de lókhos/boèlasía. A primeira dessas duas ocorrências é empregada para caracterizar Aquiles em uma breve menção, por parte de Homero, daquilo que parece ser um episódio de emboscada noturna na qual esse herói, ao embrenhar-se durante a noite no "pomar" (alóé) de Príamo (cf. ennýkbios promolón, XXI, 37), surpreende e captura Licaão, que estava entretido em cortar ramos de figueira para confeccionar um rebordo de carruagem. ${ }^{40}$ Quanto à segunda, ela ocorre em um discurso de Apolo que caracteriza Hermes como um habilidoso ladrão noturno de casas e de rebanhos, durante o primeiro enfrentamento verbal entre os dois irmãos após o furto das vacas divinas do filho de Leto praticado pelo pequeno deus, no Hino homérico a Hermes (v. 284). ${ }^{41}$

\footnotetext{
${ }^{37}$ Dué e Ebbott, 2010, p. 69-70.

${ }^{38}$ Cf. Dué e Ebbott, op. cit., p. 80-6.

39 "Mas nós reunimos, da planície, um imenso butim (677) / [...] E tudo isso para dentro de Pilo Neleia

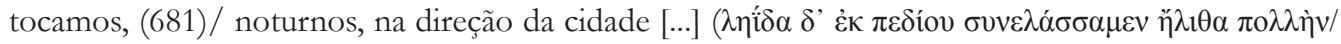

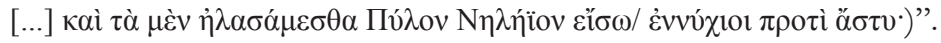

${ }^{40}$ Cf. XXI, 34-48. Para outras referências ao papel de Aquiles como emboscador noturno, conferir IX, 323-7 e os comentários de Dué e Ebbott, op. cit., p. 43-9.

${ }^{41}$ Além das passagens citadas, o adjetivo énnykh(i)os ocorre (sempre na mesma posição métrica) mais quatro vezes no corpus da épica arcaica, a saber: XI, 716 (Atena avisa, durante a noite, os pílios sobre o iminente ataque retaliatório dos epeios); iii, 177 (navios de Nestor o trazem para Geresto durante a noite); Teogonia, 10 (Musas, noturnas, encontram Hesíodo no Hélicon) e Scutum, 32 (Zeus, noturno, deixa o Olimpo para se unir a Alcmena - uma ação caracterizada como dolosa).
} 
É justamente o Hino homérico a Hermes que oferece o melhor paralelo para precisar o caráter noturno da razia de Nestor, apesar de essa composição ser muitas vezes considerada como a mais tardia e a menos tradicional do corpus hexamétrico arcaico. ${ }^{42}$ No hino, toda a narrativa da boélasía praticada pelo pequeno deus - que se estende do roubo propriamente dito, na região da Piéria, ao sacrifício ou banquete junto ao rio Alfeu, na região de Pilo - é descrita como uma ação noturna: Hermes chega ao local de pastagem do gado divino ao anoitecer (cf. a indicação temporal dos v. 68-72, em particular o imperfeito édyne, cujo sujeito é o Sol); retira suas presas do rebanho e começa a tocá-las para o Alfeu ainda durante esse mesmo período (cf. hespérios no v. 18 e o encontro com a única testemunha do roubo, um ancião que ainda labutava em sua vinha, nos v. 87-93); alcança o Alfeu no momento em que a lua acabava de atingir o zênite (v. 97-104); esconde seu butim em uma caverna, prepara seu sacrifício ou repasto e apaga (parte) dos indícios de suas atividades durante o restante da noite (cf. pannýkhios e a referência ao brilho da lua no v. 141); em seguida, volta para seu berço (despercebido de deuses, homens e cães, v. 144-5) no crepúsculo (cf. órthios, v. 143).

Dados os já apontados laços entre a dicção do Hino homérico a Hermes e aquela da boèlasía de Nestor, não é absurdo supor que o conciso episódio da Ilíada também envolveria (de modo implícito) um contexto semelhante: o gado tocado à noite, após uma razia ao entardecer. Essa hipótese é reforçada pelo fato de que, aqui, não apenas o momento do ataque se assemelharia àquele de Hermes, mas também o destino das reses roubadas, pois a geografia da passagem iliádica parece situar a ação (e, por extensão, o território de Pilo) nas proximidades do rio Alfeu, como no caso do hino. ${ }^{43}$

Além do Hino homérico a Hermes, outros episódios do épos arcaico também portadores de sobreposição de dicção tradicional com o relato de Nestor contêm elementos que

${ }^{42}$ Cf. os comentários de West, 2003b, p. 12-4. As hipóteses mais recentes para a data de composição do Hino homérico a Hermes variam, grosso modo, entre a primeira metade do séc. VI (cf. Richardson, 2010, p. 24-5), o final do séc. VI (Vergados, 2013, p. 145-7) e a primeira metade do século V (West, 2003b, p. 14). A respeito dessas questões, é proveitoso citar a porcentagem, calculada por Richardson, para o emprego do que parece ser dicção não tradicional no Hino homérico a Hermes, a saber: 4\%. Segundo esse último comentador (op. cit., p. 23-4), apesar de o Hino homérico a Hermes comportar uma maior proporção de termos únicos ou tardios quando comparado aos outros hinos homéricos e ao restante do corpus hexamétrico arcaico, tal dado comprovaria que "the overall linguistic effect is not so different from that of the other hymns, or indeed of early hexameter poetry in general". Tais formulações reforçam a abordagem adotada neste artigo, que consiste em considerar que todos os textos supérstites do épos arcaico - apesar das suas diferentes particularidades genéricas e diversas datas de composição - fazem parte de uma mesma tradição poética, podendo, assim, com alguma cautela, ser recebidos, fruídos e interpretados como um conjunto. Para as bases teóricas dessa abordagem, cf. Clay, 2006 [1989], p. 3-16 e Graziosi e Haubold, 2005, p. 18-62 passim.

${ }^{43}$ Cf. Hainsworth, 1993, ad. XI, 670-762 e Hino homérico a Hermes, 101-4, 215-6, 340-1, 354-5 e 397-8. Para Nobili (2011, p. 23-37), essa convergência geográfica entre a razia de gado iliádica de Nestor e aquela do Hino homérico a Hermes é um indício da influência originária, em ambos os episódios, de um conjunto de tradições épicas do Peloponeso Ocidental centradas em torno do reino micênico de Pilo que teriam narrativas (iniciáticas) de roubo de gado como temática recorrente. 
sugerem que o roubo de reses é tradicionalmente associado a um cenário noturno. Um exemplo bastante valioso (e problemático) é a narrativa de Odisseu acerca do ataque dos seus companheiros ao gado de Hélio em Trinácia (xii, 260-425).

É certo que, também nesse episódio, não há nenhuma indicação textual que aponte o momento específico em que o sacrifício (um ato em geral diurno) das vacas divinas acontece. Somos informados apenas de que, no momento em que os seus camaradas (sob a liderança de Euríloco) planejavam e davam início ao crime, Odisseu havia se afastado para rezar e havia adormecido (v. 333-65). ${ }^{44}$ Mas se esses elementos típicos do herói vagando sozinho, do líder exausto que dorme abandonando a vigilância e do sacrifício apontam para um cenário diurno, o fato inusitado de Hélio necessitar de uma mensageira (sua filha, a pastora Lampécia, v. 374-6) para ter ciência do ocorrido sugere, por outro lado, que o ataque aos rebanhos também pode ser entendido (ao menos de início) como uma ação noturna. ${ }^{45}$ Afinal, como explicar que Hélio - uma divindade muitas vezes referida por meio da fórmula "aquele que tudo vê e que tudo ouve (hòs pánt' ephorâi kaì pánt' epakoúei, xii, 323)" - não tenha visto justo a matança das suas vacas? ${ }^{46}$

Em comparação com essa ambiguidade do episódio das vacas do Sol, a narrativa das desventuras sofridas por Odisseu e seus companheiros junto ao ciclope Polifemo é bem mais clara em relação ao momento e às condições em que as ovelhas do ciclope são furtadas (ix, 105-566). Nesse episódio, o roubo dos animais não é o motor principal do enredo, apesar de ele ser referido como uma possibilidade desde o princípio. ${ }^{47}$ Antes, ele figura de forma incidental, mas como o ponto culminante do conflito entre a mêtis de Odisseu e a bié descomunal do Ciclope, pois as ovelhas roubadas são usadas como um dolo ou disfarce que permite aos itacenses escaparem da vigilância e do antro do seu monstruoso hospedeiro. Porém, aqui o dado fundamental para a discussão em curso é o fato de que toda a preparação

\footnotetext{
${ }^{44}$ Esses mesmos motivos típicos do herói/líder vagando só e do sono como o momento de deslize do líder atento também estão presentes no relato inicial da estadia de Menelau e seus camaradas na ilha de Faro (iv, 351-69) e no lamentável desfecho do episódio de Éolo (x, 28-76). Acerca desses dois elementos e das demais questões relativas ao modo como a Odisseia representa o relacionamento entre Odisseu e seus companheiros, cf. Werner, 2005, p. 9-29.

${ }^{45}$ Para uma proposição antiga da hipótese de um ataque noturno, cf. schol. BQ ad xii, 374.

${ }^{46}$ Vacas estimadíssimas, "com as quais eu/ costumava me deleitar quando subia ao céu resplendente/ e sempre que, de novo, voltava do céu para a terra", como afirma o próprio deus (cf. xii, 379-81). A fórmula citada acima ocorre também em III, 277 (Agamenão toma Hélio por testemunha durante um juramento) e em mais dois passos relativos ao episódio da Trinácia, a saber: xi, 109 (Tirésias adverte Odisseu acerca das vacas do Sol) e xii, 320-3 (Odisseu solicita, pela segunda vez, aos seus camaradas que evitem os animais divinos). Para outras passagens do épos arcaico que apresentam Hélio como uma divindade onividente, cf.: XIV, 341-5; XIX, 258-65; viii, 266-302; Hino homérico a Deméter, 22-6 e 62-87; Hino homérico a Hermes, 381.

${ }^{47}$ Cf. ix, 216-30 (assim que chegam ao antro de Polifemo, os homens de Odisseu desejam voltar para a nau levando queijos e reses, mas são detidos por seu líder) e ix, 399-412 (ciclopes das redondezas, alertados pelos berros do, agora, cego Polifemo, perguntam ao seu vizinho se ele grita por ter suas reses roubadas ou por estar sendo assassinado).
} 
para a fuga (e o consequente roubo dos animais) acontece no ambiente duplamente sombrio da caverna do Ciclope e da noite (v. 415-36), deixando apenas o escape efetivo e a distribuição posterior das reses entre Odisseu e seus homens como acontecimentos diurnos (v. 437-555). ${ }^{48}$

Essa forte associação entre o roubo de gado e o ambiente noturno também é verificável nos símiles, seja quando os predadores são identificados como outros seres humanos - como na breve comparação que aproxima a poeira levantada pelo avanço dos contingentes aqueu e troiano à neblina acumulada nos picos de uma montanha (III, 10-4), neblina “que para os pastores não é propícia, mas para o ladrão é melhor que a noite,/ pois só é possível ver adiante a distância de um arremesso de pedra” (III, 11-2) - seja na condição mais comum, quando os predadores são feras selvagens, ilustrada pelo conciso exemplo abaixo (XV, 323-7):

E tal como a uma boiada ou a um grande rebanho de ovelhas duas feras alvoraçam na calada da noite negra, surgindo de súbito quando o pastor não está presente; assim os débeis aqueus foram repelidos, pois Apolo neles provocou a fuga e concedia a glória a Heitor e aos troianos. ${ }^{49}$

Conforme já comentado, símiles como esse compartilham com as narrativas de razia de gado um cenário campestre, marcado pelo isolamento geográfico e social e pelas (potenciais) falta de vigilância e inépcia marcial dos pastores. O fato de um cenário semelhante (mas agora não necessariamente pastoril) também ser comum em contextos de emboscada propriamente dita talvez possa explicar as semelhanças entre esses três componentes do épos arcaico naquilo que diz respeito à representação do isolamento e despreparo das vítimas e à representação do ataque surpresa e (quando aplicável) da técnica ardilosa dos atacantes. ${ }^{50}$

\footnotetext{
${ }^{48}$ Note-se como os dezessete versos que descrevem a preparação noturna da fuga dos itacenses (ix, 420-36) concentram vários dos elementos caracterizadores da temática do lókhos, tais como: o recurso à astúcia e ao planejamento como forma de lidar com uma condição extrema (como sair da caverna passando por Polifemo?); o emprego de vestuário e implementos inusitados, mas adequados à circunstância em questão (com a devida ressalva de que, nesse episódio, os “emboscadores" de fato se disfarçam de animais, em vez de apenas vestirem roupas confeccionadas com peles); e a representação dos envolvidos no ato de lókhos em situações de desconforto físico (Odisseu enfatiza o desconforto causado pelas ovelhas-disfarce nos v. 435-6). Acerca dessas questões, cf. Dué e Ebbott, 2010, p. 84-7.

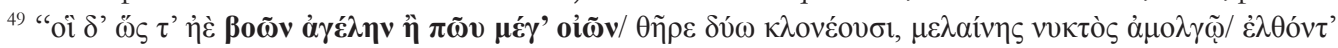

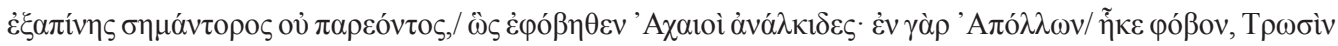

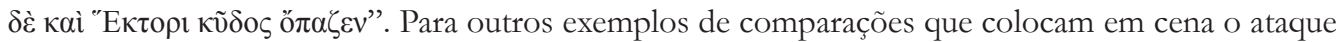
noturno de feras contra gado, cf: X, 183-9, XI, 172-8; XI, 544-57 (cf. nota 10 supra), XII, 299-308 (cf. nota 26 supra) e XVII, 656-77.

${ }^{50}$ É preciso lembrar, porém, que o isolamento das vítimas e o elemento surpresa nem sempre são garantias de sucesso para os atacantes, como mostram as comparações nas quais os pastores e seus cães conseguem impedir que as feras selvagens matem o gado (cf. os exemplos citados na nota 31 supra) e os episódios da emboscada dos cinquenta cadmeios contra Tideu (IV, 370-400) e da elite dos lícios contra Belerofonte (VI, 187-90).
} 
De fato, embora alguns dos mais famosos episódios de lókhoi narrados e aludidos na tradição épica arcaica tenham como cenário as proximidades ou mesmo o interior de póleis e $o \hat{\imath} k o i$, outros são situados em zonas campestres isoladas, locais semelhantes ao ambiente das razias de gado e das imagens dos símiles. ${ }^{51}$ É nesse cenário ermo, longe dos olhares dos outros itacenses, que Antínoo propõe aos outros pretendentes armar uma segunda emboscada para Telêmaco (que se demorava junto aos pastores, após retornar de Esparta), "tomando-o no campo (ep’ agrồ), longe da cidade, / ou no caminho [para a mesma]” (xvi, 364-92). Em outro passo do mesmo poema, é o próprio Odisseu, sob o disfarce de uma das suas personae cretenses, que afirma a Atena ter matado um desafeto quando este retornava "do campo (agróthen), após tê-lo emboscado perto de uma estrada, com a ajuda de um companheiro", sob a cobertura de uma "noite muito escura" (nýx mála dnopheré) e de forma despercebida para outros homens (xiii, 256-73)..$^{52}$

Acerca desse ponto, um paralelo bastante proveitoso é, mais uma vez, fornecido pela emboscada/razia de gado representada no escudo de Aquiles (XVIII, 509-40). Nessa belíssima cena, quando os sitiados decidem atacar as reses de seus atacantes, eles deixam a cidade sob o comando de Ares e Atena (v. 516, cf. característica 'c', supra). Em seguida, após chegarem ao ponto que thes parece ideal para a emboscada (a aguada, onde as reses costumam beber), postam duas sentinelas à frente, para espiarem a aproximação do rebanho e de seus condutores (v. 520-4). Assim que o rebanho é avistado, os emboscadores atacam, circundam o gado e matam os pastores (v. 525-9). Ao contrário do que acontece no conciso relato da razia de gado de Nestor, aqui os elementos do ataque surpresa e da falta de preparo das vítimas são explicitados, mediante a representação do rápido movimento dos emboscadores para fora do seu esconderijo e em direção às vítimas e por meio da presença dos dois pastores que guardam o rebanho e que, "deleitando-se com suas siringes, não anteciparam o dolo". 53

Diante desses paralelos e com base na hipótese de que todos ou boa parte desses episódios e situações de razia campestre e de emboscada (e mesmo os símiles que colocam em cena o ataque a gado) devem compartilhar de um mesmo conjunto de associações temáticas tradicionais (afinal, eles partilham dicção tradicional, e tema e dicção são inseparáveis), como não entender que esses motivos do isolamento e despreparo da vítima e do ataque surpresa e técnica ardilosa dos atacantes também não estariam potencialmente presentes em outros

\footnotetext{
${ }^{51}$ Para lókhoi que têm como cenário o ambiente urbano ou o interior de uma casa, conferir, e.g.: iv, 235-64 (a missão de reconhecimento de Odisseu em Troia); iv, 265-89, viii, 485-520 e xi, 505-37 (o estratagema do cavalo de madeira e o saque de Troia); iv, 512-37 e xi, 404-34 (o assassinato de Agamenão por Egisto e Clitemnestra); e a matança dos pretendentes (cuja preparação e execução ocupa boa parte da segunda metade da Odisseia), cf. Edwards, 1985, p. 35-41.

${ }^{52}$ Uma situação bem semelhante àquela da captura (e morte) do espião troiano Dolão por Odisseu e Diomedes na Dolonia (X, 299-452), como apontam Dué e Ebbott (2010, p. 73). As emboscadas frustradas contra Tideu e Belerofonte também têm como cenário o isolamento de uma via durante a viagem de retorno. Sobre o campo e o caminho de retorno para casa como cenários típicos de emboscada, cf. Edwards, op. cit., p. 22-31 passim.

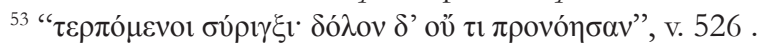


episódios, mesmo naqueles relatados de forma bastante concisa, como as numerosas razias de gado praticadas por Aquiles no monte Ida?

Voltando à boèlasía de Nestor, embora o velho líder pílio não forneça nenhuma indicação acerca do local onde se deu o ataque nem dramatize o assalto, a simples menção a um membro da elite morto "no ato de defender seus bois" (amýnōn hêisi bóessin, v. 674) e na companhia de "campônios" (agroiôtai, v. 676) coloca toda a ação, como vimos, em um cenário bastante diverso daquele da peleja iliádica convencional e sugere (metonimicamente e para um público familiarizado com os protocolos e conteúdos tradicionais do épos arcaico) que Nestor e seu bando agiram com astúcia e acabaram por surpreender Itimoneu e seus camaradas em um local isolado, quando estes não antecipavam o ataque. ${ }^{54}$

Por fim, também o contexto gerador da razia de Nestor parece se adequar às circunstâncias motivadoras de uma ação de lókhos, conforme descritas por Dué e Ebbott. Segundo as autoras, a decisão de empreender uma missão de espionagem ou uma emboscada nasce muitas vezes de uma conjuntura de desespero ou da necessidade de vencer um inimigo que não pôde ou não pode ser derrotado por meio da batalha convencional. ${ }^{55} \mathrm{Nessa}$ direção, o estratagema do cavalo de madeira - uma côncava tocaia (kốlos lókhos, iv, 277) que acaba por garantir a queda de Troia após nove anos de combates - e a emboscada/razia de gado praticada pelos habitantes da cidade sitiada no escudo de Aquiles constituem bons exemplos de lókhoi como modos de escapar da aporia imposta por uma condição desesperadora.

Mas e quanto a Pilo no momento da juventude de Nestor? Ora, como relata o próprio filho de Peleu, o estado de Pilo não era muito diferente. Desprovidos de braços e de seus melhores guerreiros (os onze filhos de Neleu, mortos por Héracles em um conflito anterior), os pílios se encontravam sem uma liderança guerreira efetiva, sendo, por causa disso, constantemente submetidos às violências (talvez razias de gado) da parte de seus vizinhos epeios (v. 685-703).

É diante desse contexto desesperador que o jovem Nestor, o único filho de Neleu sobrevivente, assume seu lugar na comunidade pília, ocupando o espaço vazio deixado pela morte de seus irmãos e tornando-se ele mesmo um áristos. ${ }^{56} \mathrm{E}$ bastante significativo o fato

\footnotetext{
${ }^{54}$ Nessa perspectiva, as expressões destacadas funcionariam como sémata (conforme a terminologia proposta por John Miles Foley), ou seja: como índices que apontam para uma rede de conteúdos tradicionais implicados. Cf. Foley, 1999, p. 1-34 passim.

${ }^{55}$ Cf. Dué e Ebbott, 2010, p. 70.

${ }^{56}$ Para referências à juventude e inexperiência de Nestor, cf. nota 9, supra. Se, após a captura das numerosas reses de Itimoneu, Peleu (apesar de contente pelo sucesso inicial de Nestor) ainda se mostrava receoso em permitir que seu único filho restante participasse de uma batalha campal (algo, afinal, bem diferente de uma escaramuça campestre contra pastores isolados), o estatuto marcial pleno do jovem herói é inquestionável após a inesperada e excepcional vitória do exército pílio, liderado por ele (XI, 753-60). Nessa direção, os versos finais da narrativa do ancião (logo após a descrição da fuga dos epeios para fora do território de Pilo) parecem funcionar (dentre outras coisas) como uma comemoração do reconhecimento da sua nova condição no interior da comunidade pília: 'Lá, após matar o último homem, o deixei. Mas os aqueus/ começaram a guiar os cavalos velozes de volta, de
} 
de Nestor praticar, nesse que parece ser o princípio mesmo da sua atividade bélica, uma razia de gado, um ato marcado (como vimos) pela ação noturna e furtiva e pelo recurso ao planejamento e à inteligência.

\section{ConsideraÇões Finais}

A análise da boèlasía de Nestor e de outros episódios paralelos efetuada acima permite confirmar a sugestão de Dué e Ebbott acerca da forte relação entre o roubo de gado e a poética do lókhos. O reconhecimento dessa relação, na medida em que insere a boèlasía em uma estrutura temática maior, permite preencher as lacunas das sintéticas narrativas e referências disponíveis nos textos supérstites, ajudando a aprimorar o desenho, já esboçado, das principais características dessa atividade, como pode ser conferido no quadro abaixo:

\section{QUADRO 2}

\begin{tabular}{|l|l|l|}
\hline \multicolumn{1}{|c|}{ Razia ou combate campestre } & \multicolumn{1}{c|}{ Batalha campal } \\
\hline Oponentes/vítimas & agrós, locais de pastoreio & $\begin{array}{l}\text { pedion, cercanias imediatas de } \\
\text { uma pólis }\end{array}$ \\
\hline $\begin{array}{l}\text { postores (jovens oriundos de famílias } \\
\text { campônios) }\end{array}$ & campeões e tropas inimigas \\
adquiridos & $\begin{array}{l}\text { principalmente gado, mas também cavalos } \\
\text { e (por vezes) escravos (pastores, crianças, } \\
\text { mulheres) }\end{array}$ & $\begin{array}{l}\text { keimétlia, implementos de guerra, } \\
\text { cavalos e carros, escravos } \\
\text { (crianças e mulheres - oriundos } \\
\text { de famílias da elite ou não) }\end{array}$ \\
\hline Modo de operação & $\begin{array}{l}\text { lókhos (caracterizado pelo emprego } \\
\text { pronunciado da mêtis, pelo cenário muitas } \\
\text { vezes noturno e pela ação furtiva) }\end{array}$ & $\begin{array}{l}\text { pólemos (enfrentamento diurno, } \\
\text { direto e aberto, cuja qualidade } \\
\text { fundamental é a bíe) }\end{array}$ \\
\hline Atacantes & Atacante/ladrão solitário ou pequeno grupo & campeões e tropas \\
\hline
\end{tabular}

Ao final dessa exposição, a boëlasía surge, então, como a principal atividade da razia campestre, uma estrutura temática do épos arcaico dedicada à representação de uma situação de combate (em geral) furtiva e noturna, ligada ao cenário marginal frequentado pelo pastor e seus rebanhos (e, portanto, contraposta à batalha campal nas cercanias de uma pólis), praticada por um agente solitário ou por um pequeno grupo de atacantes e profundamente associada ao dolo e à capacidade ambígua que lhe serve de suporte, a mêtis ou astúcia.

Por fim, retornando uma última vez ao relato de Nestor acerca do neîkos entre pílios e epeios, creio que grande parte do efeito exortativo exercido pelo ancião sobre Pátroclo deriva em grande parte da sua habilidosa exploração, em um único relato, das duas estruturas

Bouprásio para Pilo,/ e todos glorificaram Zeus, entre os deuses, e Nestor, entre os homens (andrôn)./ Assim era eu (se é que era mesmo) entre os homens (met’ andrási) [...]”, v. 759-62. 
temáticas apontadas acima. Com efeito, mediante a justaposição dessas duas situações de combate, Nestor parece fornecer a Pátroclo (para emulação) um modelo ideal de estreia no métier heroico, mediante a imagem de um jovem que se torna (no mesmo movimento) um campeão tanto na ação furtiva típica de uma razia de gado - e, aliás, seria interessante considerar se a mêtis implícita nesse ato não anteciparia de algum modo a sugestão ardilosa do uso da armadura de Aquiles por Pátroclo - como no enfrentamento aberto e direto de uma batalha campal.

De qualquer modo, seja qual for o segredo da estratégia retórica empregada pelo velho líder pílio, sua efetividade é bem conhecida, pois Pátroclo (movido por esse relato e pelas palavras posteriores de Nestor) decide enfrentar Aquiles e acaba por trazer os mirmidões de volta para a luta, tornando-se assim (embora com consequências fatais para si mesmo) uma salvação e uma luz para os dânaos (cf. XI,797 e XVI, 39) - tal como Nestor foi para os pílios.

\section{REFERÊNCIAS}

BENVENISTE, E. Vocabulário das instituições indo-européias. V. I. São Paulo: Editora da Unicamp, 1995 [1969].

CHANTRAINE, P. Dictionnaire étymologique de la langue grecque. Histoire des mots. Paris: Klincksieck, 1968-77, $2 \mathrm{v}$.

CLAY, J. S. The Politics of Olympus. 2nd ed. Bristol: Bristol Classical Press, 2006 [1989].

DINDORF, Wilhelm (ed.). Scholia graeca in Homeri Odysseam. Oxford: E Typographeo Academico, $1855,2 \mathrm{v}$.

DONLAN, W. Homeric $\tau \varepsilon \dot{\varepsilon} \mu \varepsilon v o \varsigma$ and the land economy of the Dark Age. Museum Helveticum, v. XLVI, p. 129-145, 1989.

DONLAN, W. The homeric economy. In: MORRIS, I.; POWELL, B. (ed.). A new companion to Homer. Leiden: Brill, 1997, p. 667-649.

DUÉ, C.; EBBOTT, M. Iliad 10 and the poetics of ambush. Washington: Center for Hellenic Studies, 2010.

EDWARDS, A. Acbilles in the Odyssey. Königstein: Anton Hain, 1985.

EDWARDS, M. The Iliad: a commentary. V. V. Cambridge: Cambridge University Press, 1991.

FINKELBERG, M. (ed.). The Homer encyclopedia. London: Blackwell, 2011.

FOLEY, J. M. Homer's traditional art. Philadelphia: Pennsylvania State University Press, 1999.

FOLEY, J. M. Oral tradition and its implications. In: MORRIS, I.; POWELL, B. (ed.). A new companion to Homer. Leiden: Brill: 1997, p. 146-173.

GRAZIOSI, B.; HAUBOLD, J. Homer: The Resonance of Epic. London: Duckworth, 2005.

GRAZIOSI, B.; HAUBOLD, J. Iliad: book VI. Cambridge: Cambridge University Press, 2010. 
HAINSWORTH, B. The Iliad: a commentary. V. III. Cambridge: Cambridge University Press, 1993.

HAUBOLD, J. Homer's people: epic poetry and social formation. Cambridge: Cambridge University Press, 2000.

INSTITUTO Antônio Houaiss. Dicionário eletrônico Houaiss da Lingua Portuguesa 3.0. Rio de Janeiro: Objetiva, 2009 (CD-ROM).

de JONG, Irene. A narratological commentary on the Odyssey. Cambridge: Cambridge University Press, 2001.

KAHANE, A; MUELLER, M.; et alii (ed.). The Chicago Homer. Northwestern University. Disponível em: < http://digital.library.northwestern.edu/homer/>. Acesso em: 2013.

KELLY, A. A referential commentary and lexicon to Iliad VIII. Oxford: Oxford University Press, 2007.

KNOX, M. O. Huts and farm buildings in Homer. The Classical Quarterly, v. XXI, n. 1, p. 27-31, 1971.

LEAF, W. A companion to the Iliad for English readers. London: Macmillan, 1892.

LIDDELL, H. G; SCOTT, R.; JONES, H. S. Greek-English lexicon. 9 ed. (with a revised supplement). Oxford: Oxford University Press, 1996.

LORD, A. B. Composition by theme in Homer and southslavic epos. Transactions and Proceedings of the American Philological Association, v. LXXXII, p. 71-80, 1951.

LORD, A. B. The singer of tales. 2nd ed. (edited by Stephen Mitchell \& Gregory Nagy). Cambridge Mass.: Harvard University Press, 2000 [1960].

MARTIN, R. Wrapping Homer up: cohesion, discourse and deviation in the Iliad. In: SHARROCK, A.; MORALES, H. (ed.). Intratextuality: Greek and Roman textual relations. Oxford: Oxford University Press, 2003, p. 43-65.

NAGY, G. Greek mythology and poetics. Ithaca: Cornell University Press, 1990.

NAGY, G. Homeric questions. Austin: University of Texas Press, 1996.

NOBILI, C. L'Inno omerico a Ermes e le tradizioni locali. Milano: LED, 2011.

PEDRICK, V. The paradigmatic nature of Nestor's speech in Iliad 11. Transactions of the American Philological Association, v. CXIII, p. 55-68, 1983.

PRITCHETT, W. K. The Greek state on war. Part V. Berkeley: University of California Press, 1991.

RAAFLAUB, K. Politics and interstate relations in the word of early Greek poleis: Homer and beyond. Antichthon, v. XXXI, p. 1-27, 1997. 
REDFIELD, James. Nature and culture in the Iliad: the tragedy of Hector. 2nd ed. Durham, London: Duke University Press, 1994 [1975].

RICHARDSON, N. Three Homeric Hymns: to Apollo, Hermes, and Aphrodite. Cambridge: Cambridge University Press: 2010.

SOUZA, Philip de. Piracy in the Graeco-Roman world. Cambridge: Cambridge University Press, 1999.

THES AURUS LINGUAE GRAECAE. Irvine: University of California. Disponível em: <http://www.tlg.uci.edu/>. Acesso em: 2013.

THIEL, H. van. Homeri Odyssea. Hildesheim: Olms, 1991.

THIEL, H. van. Homeri Ilias. Iterum recognovit. Hildesheim: Olms, 2010.

VERGADOS, A. The Homeric Hymn to Hermes: introduction, text and commentary. Berlin: De Gruyter, 2013.

WEES, H. van. Status warriors: war, violence and society in Homer and history. Amsterdam: Gieben, 1992.

WERNER, C. Os limites da autoridade de Odisseu na Odisseia. Caliope, n. XIII, p. 9-29, 2005.

WEST, M. L. Greek epicfragments. Cambridge Mass.: Harvard University Press, 2003 a.

WEST, M. L. Homeric Hymns, Homeric Apocrypha, Lives of Homer. Cambridge Mass.: Harvard University Press, 2003b.

WEST, M. L. The making of the Iliad: disquisition and analytical commentary. Oxford: Oxford University Press, 2011.

WILLCOCK, M. Homer's Iliad (I-XII). Bristol: Bristol Classical Press, 2009 [1978]. 